NBER WORKING PAPER SERIES

\author{
THE POLITICAL ECONOMY \\ OF FISCAL POLICY
}

Danie1 E. Ingberman

Robert P. Inman

Working Paper No. 2405

\author{
NATIONAL BUREAU OF ECONOMIC RESEARCH \\ 1050 Massachusetts Avenue \\ Cambridge, MA 02138 \\ October 1987
}

Inman wishes to thank the Public Policy Initiatives Fund of the University of Pennsylvania and the National Science Foundation (SES87-18768) for financial support during the writing of this survey. The research reported here is part of the NBER's research project in State and Local Finance. Any opinions expressed are those of the authors and not those of the National Bureau of Economic Research. 


\title{
The Political Economy of Fiscal Policy
}

\author{
ABSTRACT
}

If there has been a dominant trend in the evolution of the modern industrial societies of this century it has been the growing importance of government in the allocation of social resources. It is important that we appreciate the fundamentally political nature of the formation of government economic policy. This survey reviews and assesses our present understanding of how the political system might shape a nation's fiscal policy. Our approach is eclectic, drawing both from economics and political science, and decidedly micro-analytic in its orientation. From economics we adopt the perspective of utility maximizing agents and the analytics of trade, agreement, and market failure. From political science we learn just how and when these individual agents might act collectively to provide public goods, redistribute income, or issue government debt. Together the micro-analytics of economics and political science form the core theory of the 'new' political economy and provide a framework for understanding the emergence, and the performance, of governments. There is no more important test for the new discipline than providing a compelling explanation for the formation of fiscal policy in democratic societies.

Daniel E. Ingberman

The Wharton School of Management University of Pennsylvania

Philadelphia, PA 19104
Robert P. Inman

The Wharton School of Management University of Pennsylvania Philadelphia, PA 19104 


\section{INTRODUCTION}

If there has been a dominant trend in the evolution of the modern industrial societies of this century it has been the growing importance of government in the allocation of social resources. Governments provide goods and services, redistribute private income, and regulate economic activities. None of the major industrial nations now allocate less than $20 \%$ of their national income through governments. ${ }^{1}$ As public finance economists it has been our job to understand and to advise governments on how best to play this role in the economic affairs of state. Wisely or no, our advice is not often heard nor heeded. One does not have to look hard for the reason why: government officials are themselves players in the game of social resource allocation. What might be a compelling change in national fiscal policy from the perspective of economic welfare maximation may be an invitation to political defeat for a President or Prime Minister.

This pre-eminence of politics over economics does not mean that the economist has no place in the setting of fiscal policy. On the contrary, we have more than enough to do, either as impartial policy analysts, as inside political advisors, or as outside critics. In each of these roles, however, it is imperative that we appreciate - or better yet, understand - the fundamentally political nature of government economic policy. At the conclusion to their survey of modern public finance, A. B. Atkinson and J. E. Stiglitz caution that "the very real features of government behaviour -- and the wider political structure -- must be taken into account in any realistic asessment of the prospects for reform (1980, p. 576)." Understanding how this wider political

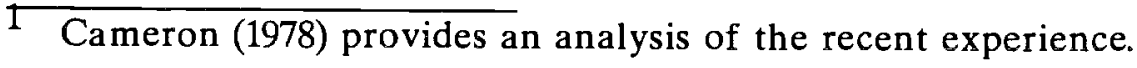


structure shapes fiscal policy is one of the central tasks of contemporary political economy.

Our approach to the political economy of fiscal policy is eclectic, drawing both from economics and from political science, and it is decidedly micro-analytic in orientation. We find unhelpful an appeal to strict economic determinism - whether neoclassical or Marxist - or a call to some unspecified political force--whether Leviathan or the benevolent philospher king-as an explanation for a nation's fiscal policy. $^{2}$ From economics we adopt the perspective of utility maximizing agents and the analytics of trade and agreement. We also find in economic theory the reasons for government, notably, the failure of markets to commensurate all beneficial trades. As Samuelson and others have noted, the essence of a market failure is the inability of individuals to act cooperatively when cooperation provides an overall (i.e., Pareto) preferred allocation. ${ }^{3}$ The potential advantage of government in this regard is that as a coercive institution it can discipline free riders and enforce some chosen collective allocation. From political science we learn just how and when such collective actions might arise to satisfy this demand for cooperative allocations. Together, the microanalytics of economics and political science form the core theory of the "new' political economy and provide us with a framework for understanding the emergence, and the performance, of governments. There is no more important test for the new discipline

2 The neo-classical position is best summarized as Wagner's Law of government growth (see Cameron, 1978), while a Marxist view of the state is presented in O'Connor (1973) or Jessop (1977). The Leviathan view is summarized in Brennan and Buchanan (1980) while the theory of the state under a philosopher king is, in effect, neo-classical welfare economics applied to issues of public finance (see Atkinson and Stiglitz, 1980).

3 See Inman (1987c) for a review of the market failure literature from this perspective. 
than providing a compelling explanation for the formation of fiscal policy in democratic societies. ${ }^{4}$

Before putting the new political economy to the test, however, it will be helpful if we briefly review the simple analytics of collective decision-making. Section II provides that review by focusing on one question of central importance: When will majority-rule governments succeed in making collective choices which, given the exact institutions which are in place, no individual or group has both the incentive and the ability to change the resulting allocation? We shall see that with a simple majority-rule process with three or more voters and three or more policy alternatives there is often no such stable outcome. This is a distressing result. It implies, first, that majority-rule processes often cannot guarantee an efficient allocation will be stable and, second, prediction of a chosen allocation at a given point in time may not be possible. Fortunately, real democracies move beyond simple majority-rule to more structured collective choice processes. With that additional structure can come stable allocations. In Section II we characterize the essential components of these stability enhancing political institutions.

From this perspective, Section III reviews the recent theoretical and empirical literature on the democratic determination of spending, taxes, and public borrowing. Voting models assuming non-cooperative behavior and models of negotiation and coalition formation assuming cooperative behavior are reviewed. We summarize the central results of each approach. While these initial studies are encouraging, they still leave us far short of a compelling predictive political-economic model of fiscal choice from which to make recommendations for institutional reform.

4 The new political economy has also been applied with some success to explain and evaluate government regulation; see Romer and Rosenthal (1987) for a critical review of that literature. 
Section IV concludes our survey by reviewing briefly our central conclusions and by suggesting research direction which we feel hold promise for better understanding the political and economic forces which shape fiscal policy in a democratic society.

\section{THE SIMPLE ANALYTICS OF COLLECTIVE CHOICE}

As economists we are motivated to model political processes in order to understand the properties of political resource allocation. This investigation has taken two clearly discernable paths. The first, of ten referred to as social choice theory, considers the properties of collective choice mechanisms in the most abstract way possible; typically, the social choice problem only specifies the form of voters' preferences and the dimensionality of the set of feasible alternatives, and the focus is on the existence of an equilibrium, usually defined as that feasible alternative that commands a majority against any other. The social choice approach can thus be thought of a search for the properties that every majoritarian political process must possess, independent of the particular organizational details of the institutional environment in which collective decision-making takes place. Such an "institutionless" approach might provide a "long-run" description of an equilibrium to which democratic political processes converge - if there is some identifiable policy that commands a majority against any other, then most democratic or competitive institutions might be expected to approach such a policy over time. Unfortunately, the fundamental results of social choice theory show such an equilibrium exists only in very special circumstances. In general, institutionless democratic processes cycle among some or all possible outcomes without settling on a specific allocation.

In response to these negative results, a second branch of the literature has sought to understand the effects of institutional structure on the existence and 
properties of equilibria in political process. This alternative approach, of ten called the new political economy or public choice theory, expands the set of modelling considerations to examine the details of the rules or institutions governing the process at hand - for example, what constitutes an acceptable proposal and the order in which alternative proposal can be considered. From the perspective of political resource allocation, models constructed in the public choice tradition are much better behaved than their social choice counterparts: once enough institutional richness is incorporated in models of political processes, the inherent indeterminateness of institutionless democratic choice is ameliorated. The advantage of the public choice approach is that with specified and determinate outcomes, prediction - and hypothesis testing - becomes possible.

While social choice theory might well be characterized as helping us to understand the necessary trade-offs among the axioms of what should be, public choice theory is best seen as helping us to understand what is. It is to public choice theory that we turn, therefore, for guidence to understanding the formation of fiscal policy in democratic societies.

\section{A. "Institutionless" Majority Rule}

The intuitive case for simple majority rule is its administrative simplicity hold a vote and the outcome with more than half the votes wins - and the fact such a process is sensitive to citizen preferences. May (1952) formalized this intuition and showed that simple majority rule is the only social choice process which can reach a decision for all possible citizen preference orderings (it is unrestricted), that uses only these preference orderings to reach choices and therefore ignores the labels or names attached to voters (it is anonymous), that treats all alternatives equally affording no option a special position in the voting (it is neutral), and that is responsive to changes 
in voter preferences (it shows a positive association). What simple majority rule does not do, unfortunately, is guarantee a stable allocation.

A simple example due to Condorcet (1776) of majority rule voting over three alternatives - options A, B, and C - and three voters illustrates the basic problem. Table 1 lists the unrestricted preferences of these three individuals - denoted voters 1 , 2 , and 3 - over the three allocations.

\section{Table 1}

\section{VOTERS}

$\begin{array}{cccc} & \text { 1 } & 2 & 3 \\ \text { Most Preferred } & \text { A } & \text { B } & \text { C } \\ \text { OUTCOMES } & \text { B } & \text { C } & \text { A } \\ \text { Least Preferred } & \text { C } & \text { A } & \text { B }\end{array}$

Decisions will be made using pairwise majority rule. We arbitrarily and unimportantly assign $B$ to be the initial status quo, and first pair it against $A$. From the preferences specified in Table 1, persons 1 and 3 prefer $A$ to B, so option A wins. Now let $A$ be the new status quo, and pair it against $C$. Since 2 and 3 prefer $C$ to $A, C$ becomes the new status quo. But now compare B to C. B defeats $C$ with a majority composed of voters 1 and 2 . In this example, an intransitive voting cycle emerges from majority rule, since $A$ defeats $B, B$ defeats $C$, but $C$ defeats $A$. No outcome commands a majority against all other outcomes. Further, the example is robust to permutations of its special structure. If every combination of tastes is equally likely, then the probability that a voting cycle occurs is increasing in both the number of voters and the number of alternatives; see Table 2 . With 49 possible alternatives, the 
limiting probability (as the number of voters goes to infinity) of the occurance of a constellation of voters' preferences that produces a voting cycle is $8411^{5}$

Number of voters

\begin{tabular}{lccccccccccc}
$\begin{array}{l}\text { Number of } \\
\text { alternatives }\end{array}$ & 3 & 5 & 7 & 9 & 11 & $\cdots$ & 25 & $\cdots$ & 49 & $\cdots$ & $\infty$ \\
\hline 3 & .056 & .069 & .075 & .078 & .080 & .084 & .086 & .088 \\
4 & .111 & .139 & .150 & .156 & .160 & .169 & .172 & .176 \\
5 & .160 & .200 & .215 & .224 & .229 & .242 & .246 & .251 \\
6 & .202 & .251 & .271 & .281 & .228 & .303 & .309 & .315 \\
7 & .239 & .296 & .318 & & & & & .369 \\
8 & .271 & .334 & .359 & & & & & .415 \\
. & & & & & & & &. \\
. & & & & & & & &. \\
49 & & & & & & & & .841
\end{tabular}

(From P.C. Ordeshook, Game Theory and Political Theory: An Introduction, p.58.)

The example in Table 1 and the calculations of Table 2 assume that all voter preference orderings are possible and equally likely. But this extreme diversity in tastes may be rare, which suggests the existence of some empirically reasonable restriction on voters preference orderings that might allow us to escape from the problem of voting cycles. One result, due to Duncan Black $(1948,1958)$, is fundamental. ${ }^{6}$ Also known as the median voter theorem, Black's theorem shows that if the social decision problem is single-dimensional and every individual's preferences over this single dimension are single-peaked, then a stable majority rule equilibrium always exists. A collective decision problem is single-dimensional if the set of

5 These and similar calculations are found in Ordeshook (1986).

6 Sen (1966) has generalized Black's important insight. The theorem has antecedents in the earlier work of Hotelling (1929) and Bowen (1943). 
outcomes can be ordered along a line - for example, as spending levels or tax rates. Preferences are single-peaked if each voter has a most preferred outcome - a bliss point or ideal point - and utility for every other outcome decreases (weakly) monotonically with the distance between it and the ideal point.

A set of such single-peaked preference orderings for three voters is shown in Figure 1. In Figure 1, the voter with ideal point labelled $\theta_{2}$ is the median voter - at least half the voters have ideal points equal to or greater than $\theta_{2}$, and at least half have ideal points equal to or less than $\theta_{2}$. Black's Theorem then states that the median voter's ideal point is the unique, simple majority rule equilibrium. To see this, consider any other alternative, say $Z$; assume without loss of generality that $Z$ lies to the right of $\theta_{2}$. Because all voters preferences are single-peaked, all voters whose ideal points lie to the left of $\theta_{2}$ prefer $\theta_{2}$ to $\mathrm{Z}$. But by construction, all of these voters to the left of $\theta_{2}$, combined with $\theta_{2}$, comprise a majority. Thus $\theta_{2}$ defeats any alternative to its right. A similar argument shows that it also defeats any alternative to its left. ${ }^{7}$

To see how single-peakedness of voter preferences avoids a voting cycle, return to the example in Table 1. Figure 2 graphs the preferences of the three voters. No matter how we order the alternatives on a line, one voter's preferences are not singlepeaked; for example, in Figure 2c voter 3's preferences are double-peaked against the

7 An alternative proof is as follows. We restrict attention to the case of an odd number of voters; the argument for an even number is similar. Call a subset of voters that comprises a majority a majority coalition. Observe that any majority coalition either consists of voters with ideal points that all lie (weakly) to one side of the median ideal point, or it consists of voters with ideal points drawn from both sides of the median. Since preferences are single-peaked, the median ideal point is in the Pareto optimal set for every majority coalition, and is therefore in the intersection of these Pareto sets. Since the median ideal point is Pareto optimal for all possible majorities, it cannot be defeated in a pairwise vote. 
FIGURE 1

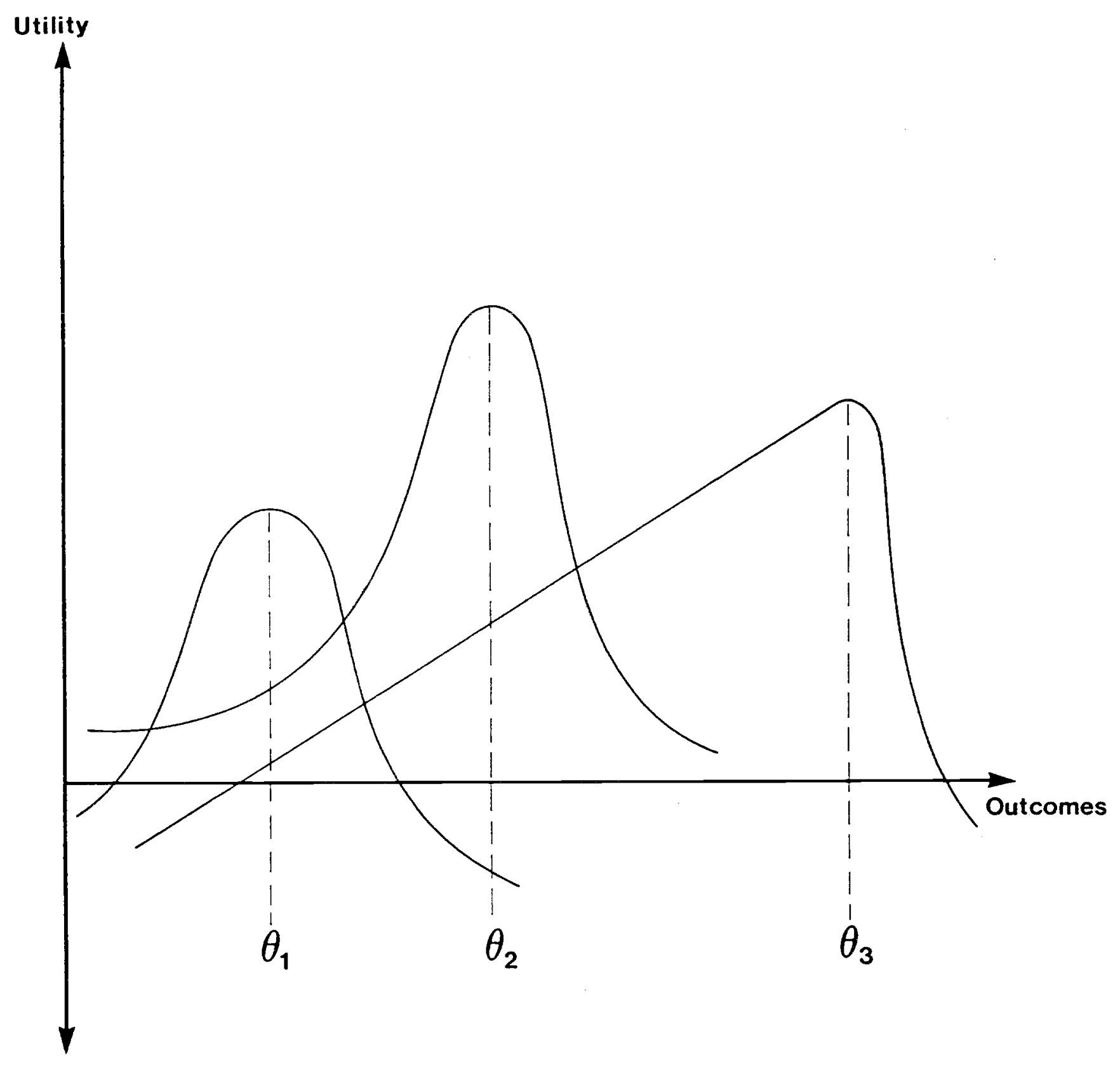


FIGURE 2

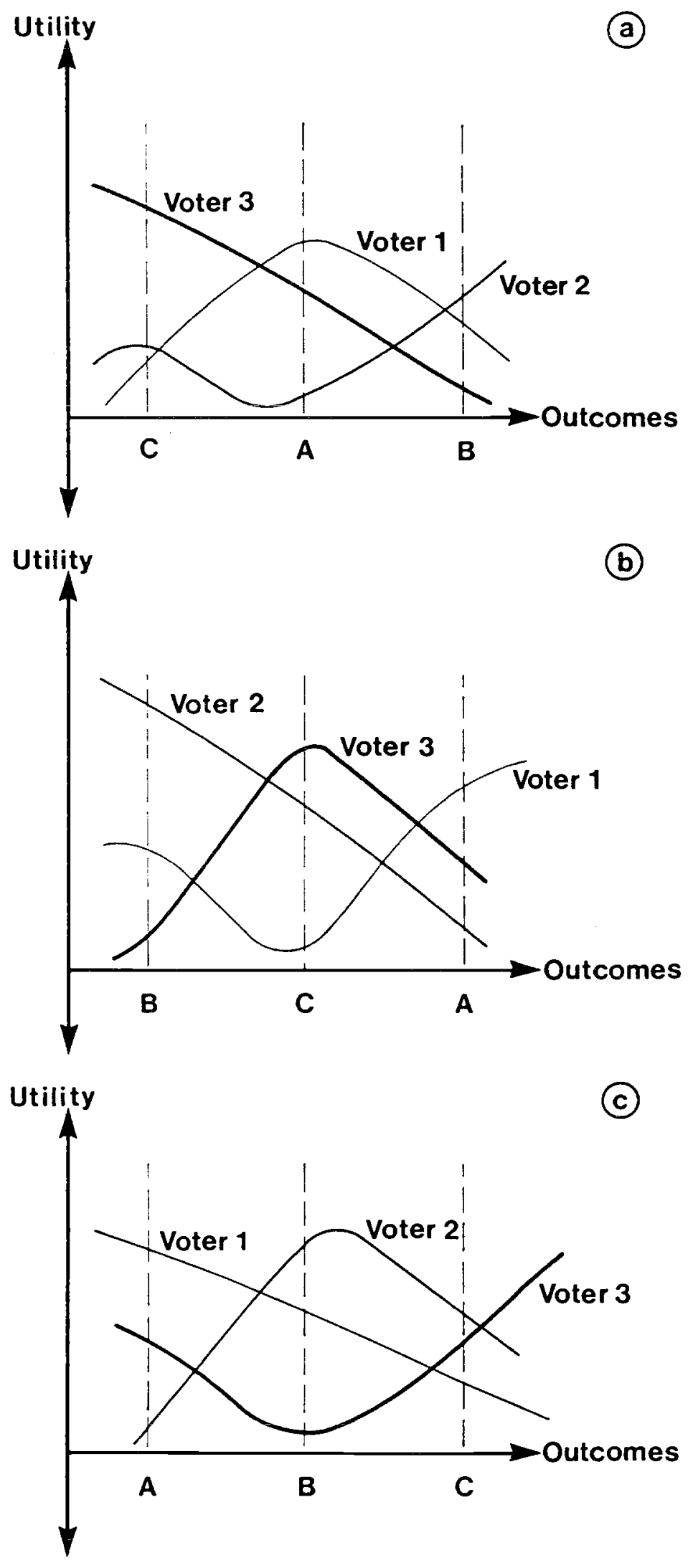


single-dimension ordering $\mathrm{ABC}^{8}$ If we disallow such a double-peaked preference ordering and substitute a single-peaked ordering for voter 3 such as $C>B>A$, then a stable majority rule outcome will result. The reader can verify that this outcome is alternative $B$.

The median voter theorem has great intuitive appeal, perhaps because the notion of single-peaked preferences defined over a single-dimension corresponds to the heuristics "left", "right", "center" that so of ten characterize colloquial political discourse. Moreover, single-peaked preferences can often be induced in natural ways from economic preferences. Figure 3a illustrates a voter's preferences for a public good $(G)$ and after-tax private income $(y)$, where $G^{*}$ indicates the voter's most preferred allocation (ideal point), given his budget constraint defined by before-tax income I and the effective "tax price" ( $\pi$ ) for a unit of $G^{9}$ Figure $3 b$ maps each level of $\mathrm{G}$ into a ranking based upon the preference ordering implicit in the indifference curves of Figure 3a. $G^{*}$ is the voter's ideal point, and feasible levels of $G$ further and further from $G^{*}$ are valued less and less. Preferences for $G$ in Figure $3 b$ are therefore single-peaked. Because single-peaked preferences are often the logical consequence of an economic demand model, the median voter theorem has formed the conceptual underpinnings for many models that have contributed to our understanding of the interaction between economic and political activity.

8 To see how Black's theorem now fails when single-peakedness does not hold, note that persons 1 and 3 prefer outcome $A$ to any outcome to its right, so A defeats all such outcomes, and in particular, A defeats B. So far so good; B - a non-median outcome - cannot be an equilibrium. But 2 and 3 both prefer $C$ to $A$, so $A$ (the median voter's ideal point) is not an equilibrium. And 1 and 2 both prefer $B$ to $C$, so $C$ cannot be an equilibrium either. Thus, no equilibrium can exist with these preferences.

9 This specification of a typical voter's demand for public goods appears in a variety of places; see Inman (1979). Denzau and Parks (1979) and Slutsky (1979) provide a general discussion of the derivation of voter preferences for public goods. 
FIGURE 3

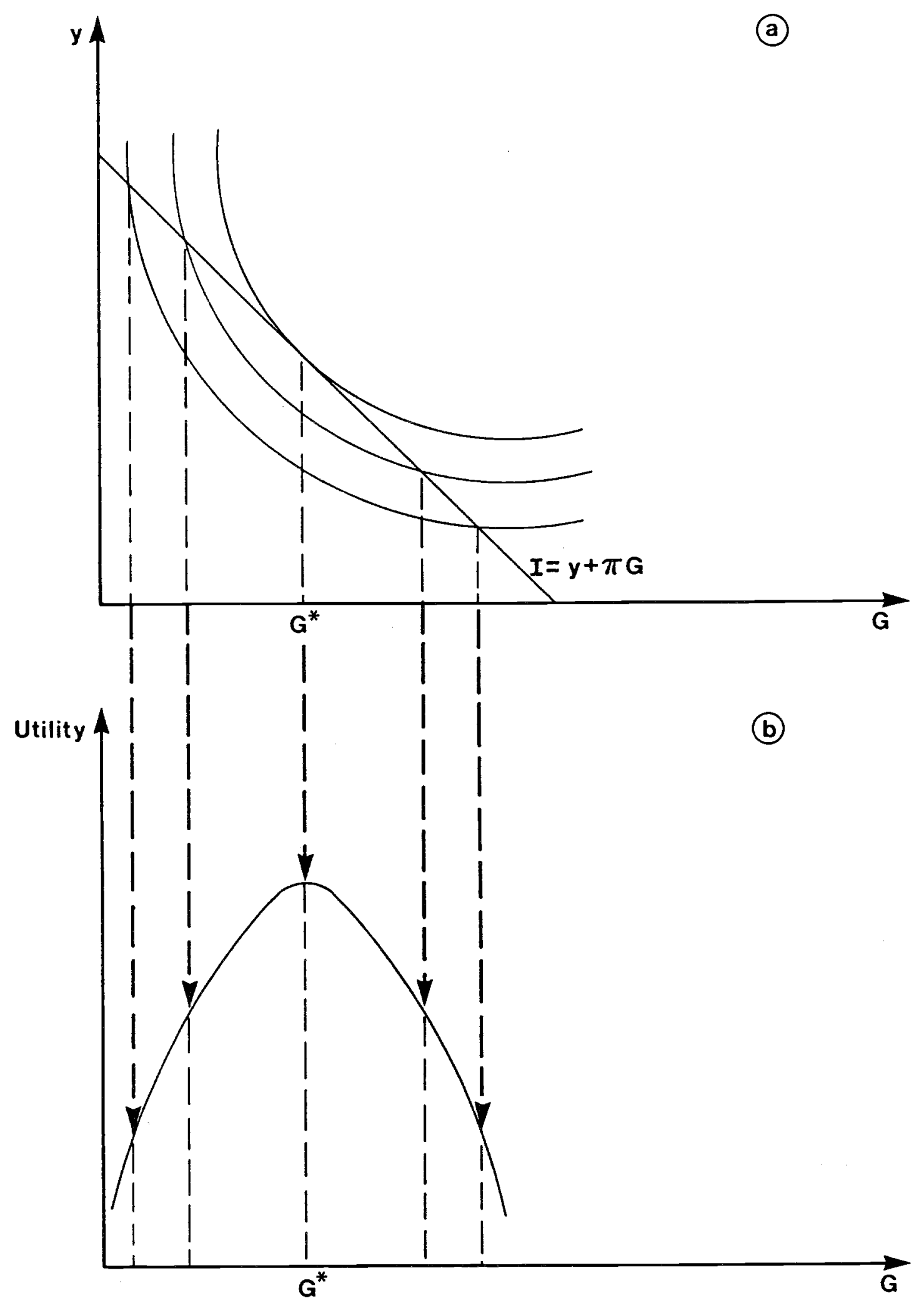


One obvious limitation of the median voter theorem, however, is its restriction to preferences defined over a single policy dimension. A natural extension is to consider restrictions akin to single-peaked preferences for multidimensional outcome spaces. For instance, suppose society now seeks to use majority rule to allocate two types of public goods, say education and defense. Assume further that each of three voters has a quasiconcave utility function defined over these goods - that is, each individual has a bliss or ideal point indicating a most preferred level of each good, with utility decreasing as the allocation moves away from the ideal point. The indifference curves that result each enclose a convex set of points, each point strictly preferred to every point on the curve. One such indifference curve for each voter is drawn (for simplicity) as a circle in Figure 4 about each voter's ideal point. ${ }^{10}$

Society now seeks to use majority voting to determine spending levels for these two publicly provided goods. Will there be a majority rule equilibrium to the resulting voting game? Not for the configuration of three voters' preferences shown in Figure 4. To see this, initially limit the analysis to those allocations within the set of outcomes that cannot be jointly improved upon for this set of voters - that is, the set of Pareto optimal outcomes. Because preferences are circular, the "contract curves" between any three pair of voters ( 1 and 2; 2 and 3; 1 and 3) are given by the straight lines connecting their ideal points. For any point outside the resulting triangle, there is at least one point within the triangle which is favored by all three voters. That is, moves into the triangle from outside constitute Pareto superior re-allocations; thus, the triangular set is often called the Pareto set of the voting game. Consider any initial status quo in the interior of the Pareto optimal set, say point $A$ in Figure 4. Take the

10 If all of a voter's indifference curves are circular, then utility is monotonic in the Euclidean distance between the voter's ideal point and the policy outcome in question. Thus, circular indifference curves are often said to result from Euclidean preferences. 
FIGURE 4

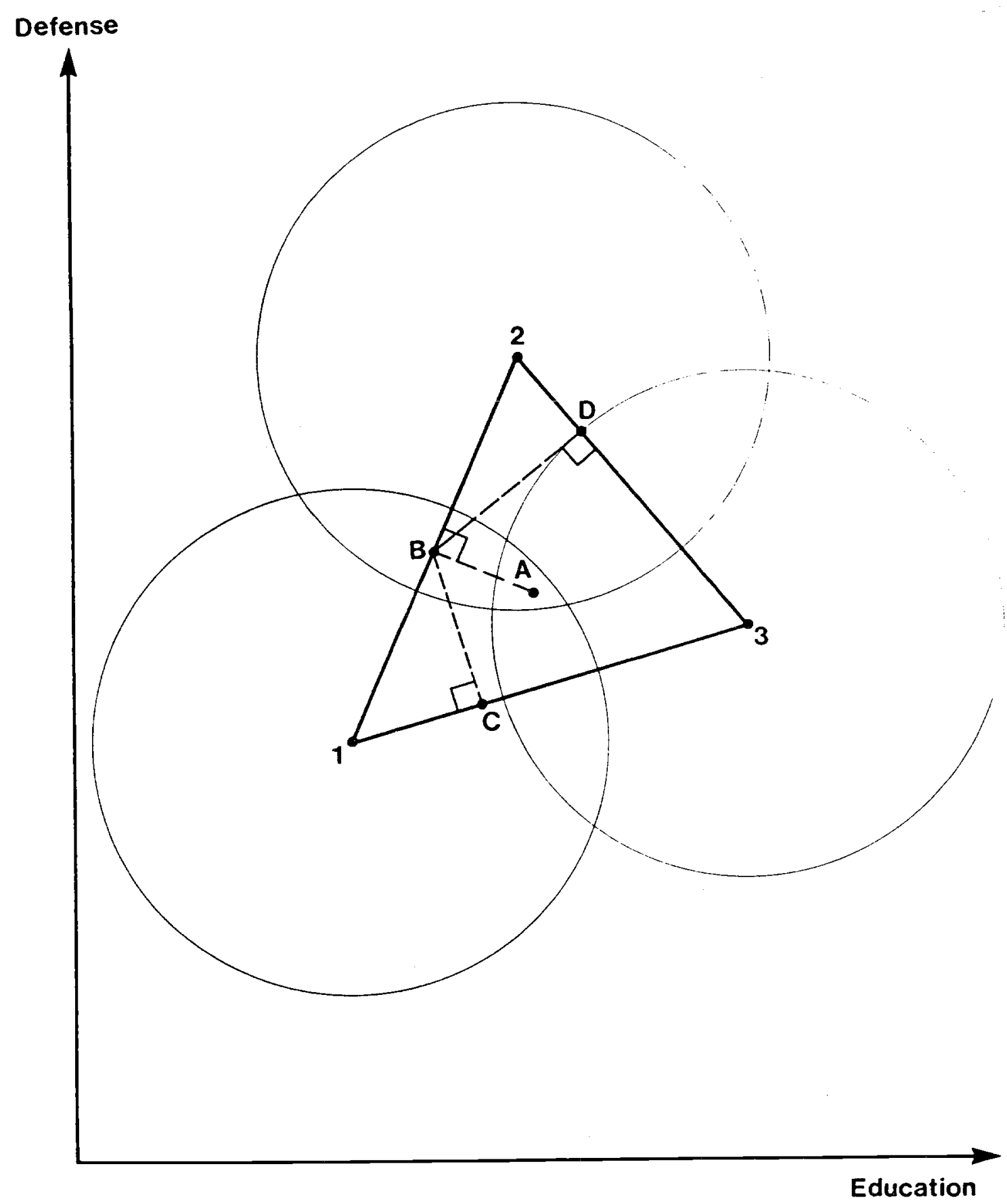


perpendicular projection of $\mathrm{A}$ onto any of the straight lines connecting the ideal points of any two voters, e.g., point B. By construction, B is closer to the ideal points of persons 1 and 2 than $A$, and because all indifference curves are circular, both 1 and 2 prefer B to A. Hence B, if proposed, commands a majority against A. But now an identical argument implies that for any such $B$, the perpendicular projections of $B$ onto each of the other two faces of the triangle (points C and D) each defeat B with a majority. Repeating a similar argument for $\mathrm{C}$ and $\mathrm{D}$ shows that no majority rule equilibrium exists in this two dimensional example. ${ }^{11}$ More generally, Plott (1967) showed that unless the distributions of voter preferences exactiy satisfies a stringent set of symmetry requirements, no majority rule equilibrium exists. ${ }^{12}$

11 Another way to see this is to recall that a majority rule equilibrium must lie in the intersection of the set of Pareto optimal outcomes for every group of voters that comprise a majority. But by construction, each of the three two-person contract curves that together form the triangle have no common intersection. Therefore, since any given point can lie on at most two sides of the triangle (a corner), for any outcome in the triangular Pareto set there always exist two voters (i) whose ideal points define a side of the triangle and (ii) both prefer some point on that side to any other point on either of the other sides, or anywhere else. Since two voters form a majority, every point can be defeated by some other.

12 Suppose all voters have circular indifference curves and that the (presumed) majority rule equilibrium point is the ideal point of only one voter. If this point is a median in all directions - if every line through that point divides the electorate into two sets such that at least half the voters' ideal points lie on or to one side of the line, and at least half lie on or to the other side of the line, then this point must be Pareto optimal for every majority coalition: no group of voters that comprise a majority will unanimously prefer this point to any other. Thus it will be a majority rule equilibrium. With circular indifference curves, a sufficient condition for the existence of a median in all directions is that the distribution voter ideal points be (radial) symmetric about this point. More generally, Plott shows that for non-circular indifference curves, it must be possible to pair each voter with another so that the contract curve between each pair intersects at this point. Again, this follows because a majority rule equilibrium point must be Pareto optimal for every group of voters that constitute a majority. But by even slightly permuting such a radially symmetric distribution of ideal points (or, more generally, permuting distributions satisfying the corresponding symmetry conditions for other forms of preferences) will revive the indeterminancy problem. And in such circumstances the model makes no predictions about the outcomes of the pure majority rule choice process, since every possible alternative can be defeated by some other. 
Where does all this leave us? We must conclude that only in very special circumstances - single dimension, single-peaked preferences or multi-dimension, symmetric preferences - can we expect simple majority rule to yield stable public choice outcomes. Otherwise, voting cycles among the available alternatives occur. This nearly complete lack of determinancy under simple majority rule voting is disturbing, for it runs counter to the observed stability in policy outcomes in most democracies.

\section{B. Political Institutions and Political Outcomes}

One resolution of this conflict between the theory of majority rule and political reality is to be found in the workings of political institutions. Public policies are rarely, if ever, enacted by a simple majority vote of all eligible citizens choosing over all policies simultaneously. Citizens often vote only issue-by-issue - on education this time, tax reform next year. Perhaps it is not even the citizens who directly decide policy but their elected agents - called "representatives" - who respond to constituents, but also may have their own preferences. And more of ten than not, collective decisions are made in legislatures, with their own unique rules for just how final policies will be decided. Such political institutions may inhibit the pervasive chaotic tendencies of simple majority rule. These institutions can be described on one or more of five dimensions, each of which can contribute to stability in democratic choice when appropriately specified. The five dimensions are: who votes, on what, when, where, and, finally, how?

\section{WHO Votes?}

Certainly one important message of the Black and Plott theorems is that preferences matter; both the existence and the location of majority rule equilibrium 
depend upon the form and distribution of voters' preferences. This is at least partially an institutional phenomenon; most democratic countries have universal enfranchisement of their citizenry. But individual citizens in most democratic countries choose whether or not to be a voter - to participate in the election - and indeed, participation is far from universal. Democratic voting seems to involve the absention of some voters even in elections as important as local tax rates or as wellpublicized as the choice of a President or Prime Minister.

Why do citizens who have the legal right to express their preferences over public policies via the vote abstain from exercising that right? One answer is that it is simply irrational to vote. Suppose there is a fixed agenda in a public referendum or election, a choice between two alternatives. Voting - and voting with care - takes time and concentration and thus inflicts costs on the participant. Compare these costs to the individual's benefits, which are bounded above by the utility difference between the competing alternatives. The expected benefit of voting is simply this difference, multiplied by the probability that the voter in question is decisive - that is, the probability that this voter makes or breaks a tie. For large numbers of other expected voters, it seems to make no sense to vote: with a large number of voters, the probability of being decisive is infinitesmally small. Against this logic, it is surprising that anyone votes at all, but they do. Ronald Reagan was almost universally expected to win the 1984 U.S. presidential election, yet more than 90 million Americans voted anyway. Moreover, large numbers of voters participated even in Hawaii, long after the media had announced (based on exit polls) that Reagan had won. Perhaps the real paradox is not why voters abstain, but rather why they vote at all!

This paradox can be resolved, however, by recognizing that universal voter abstention cannot be a stable equilibrium in voter participation strategies. If everyone was expected to abstain, then one person could dictate the outcome with their vote. 
But this does not imply that each voter would choose to vote for sure, since if everyone votes, each individual's vote will have an infinitesimal effect on the final outcome. Once again, each should now choose to abstain, since voting is costly. We seem to have uncovered yet another cycle of instability in majority rule politics.

Palfrey and Rosenthal (1985) provide a compelling resolution to this continual cycling between full voting and full abstention. They construct an equilibrium to this strategic voting game in which where each voter, given his expectations about the probability of being decisive, is just indifferent between voting and abstaining. ${ }^{13}$ Within the context of their model, they show that participation declines as the size of the electorate increases, and, importantly, in large electorates, only those voters with negative costs of voting - that is, those who derive direct benefits from the act of voting itself - will find it optimal to participate.

From our perspective of looking for stable public choice outcomes, the Palf reyRosenthal result has dual importance. First, in large elections, strategic participation in elections is no longer really an issue: only those voters who derive a direct benefit from the act of voting (e.g., "civic duty") will choose to participate. Thus we can set aside the problem of modelling the dynamics between participation and voting outcomes and take the decision to participate as exogenous. Second, there may well be a correlation between a sense of civic duty and preferences for public goods which enhances the possibility of stable majority rule outcomes.

13 A similar result was derived independently by Ledyard (1984). Both Ledyard and Palfrey and Rosenthal produce player stategies that comprise rational expectations equilibria in the sense that information is updated using Bayes rule, subject to a correct understanding of the game being played. In contrast to Palfrey and Rosenthal, who assume exogenously determined voting choices and derive comparative statics for empirical work, Ledyard allows for endogenous agendas set by competitive candidates. 


\section{On WHAT Do We Vote?}

In real democracies voting takes many forms: we vote for candidates, we choose policies directly through referenda, and we vote in legislatures. Each such election is subject to rules, both statutory and customary, and these rules often entail significant constraints on the degree of competition between policy alternatives or candidates. In the unconstrained world of open or institutionless majority rule there generally are no stable allocations, but in the constrained world of real democracies, there are. What is being voted on, and how that determination of the agenda is made, is fundamental to the characteristics and stability of outcomes in democratic policy choice.

Referenda, Legislatures, and Agendas: When a stable majority-rule equilibrium does not exist, the agenda or order of voting will completely determine the outcome of the majority rule process. To see this, return to Table 1 above and consider three alternative agendas. For concreteness, suppose that each of the outcomes $\mathrm{A}, \mathrm{B}$, and $\mathrm{C}$ represent different allocations of economic resources, and that the outcome chosen will be the social outcome. Agenda $\alpha$ first pairs A against B and then pairs the winner against $C$, agenda $\beta$ first pairs $B$ against $C$ and then pairs the winner against $A$, and agenda $\gamma$ first pairs $C$ against $A$ and then pairs the winner against $B$. Given the tastes of the three voters shown in Table 1 and the assumption that all vote for the outcome they sincerely prefer at every stage of the process, agenda $\alpha$ yields outcome $C$, ( $A$ beats $B$ and then loses to $C$ ) agenda $\beta$ yields outcome $A$, ( $B$ beats $C$ and then loses to $A$ ) agenda $\gamma$ produces outcome $B$ ( $C$ beats $A$ and then loses to $B$ ). Therefore, the outcome of this agenda-modified majority rule process is completely determined by the order of voting. With agenda setting, there is no indeterminacy. 
This observation -- that agendas are crucial determinants of outcomes - is much more general than the three voter, three alternative example of Table 1. McKelvey's $(1976,1979)$ so-called "chaos" theorems show that with $m$ voters and $n$ dimensions, if there is no stable, majority-rule winner, then there always exists a finite agenda that leads from any initial status quo to any other point and back again. ${ }^{14}$ As long as voters cast their ballots at every stage for the alternative that they truly prefer, an agenda can be designed to lead anywhere. In this sense, the observation that majority rule is used to choose among alternative policies may place few restrictions on the type of policies that emerge. Without information concerning the formation of the agenda, it appears that little can be said about the characteristics of such policies.

If agendas determine outcomes, then what determines agendas? In some cases the institutional form may limit "entry" to such an extent that the agenda - say, in a legislative process or referendum - is determined by a single individual or set of similarly motivated individuals. In that case, identifying the incentives of this monopoly agenda setter permits predictions of the properties of political resource allocations and other socially chosen outcomes. For instance, for the preferences given in Table 1, suppose one individual is the agenda setter. That individual can propose the agenda which ensures his or her favorite outcome - for example, person 1 would propose agenda $\beta$ which leads (if voting is sincere) to outcome A.

Although extreme, this story of a monopoly agenda-setter is not without its analog in actual political processes. For instance, many localities in the United States use direct democracy referenda to determine spending levels on local public goods. In these referenda, an interested bureaucrat (in the case of school expenditures, the

14 Related contributions and extensions are due to Cohen and Matthews (1980) and Schofield (1976). 
school board or superintendent of schools) proposes a budget. If a majority of voters approve the budget it is implemented and the relevant taxes collected. Otherwise, a constitutionally determined alternative budget - called the reversion - is established. ${ }^{15}$ Romer and Rosenthal (1979) have examined the theoretical and empirical implications of this institutional structure under the assumption that the monopoly agenda-setter seeks to maximize expenditures. The agenda-setter presents the voters with a take-itor-leave-it choice between its proposed budget for the public good $\mathrm{G}$ and some reversion allocation, R. Figure 5 reproduces the (induced) preference ordering of voter $i$ over alternative levels of $G$. For any reversion $R$, define $E_{i}^{+}(R)$ as the most expenditure on $\mathrm{G}$ voter $i$ would accept, given $\mathrm{R}$. Then the assumption of a budgetmaximizing agenda setter leads to the prediction that the equilibrium budget equals $\mathrm{E}_{m}{ }^{+}(\mathrm{R})$, the median value of $\mathrm{E}_{i}^{+}(\mathrm{R})$. Furthermore, the model predicts a particular relationship between the reversion $R$ and the level of the final budget. Assume for simplicity that $\mathrm{E}_{i}^{+}(\mathrm{R})$ is proportional to $\mathrm{G}_{i}^{*}$, so that the voter with the median ideal point is also the voter with the median $\mathrm{E}_{i}^{+}(\mathrm{R})$. As long as $\mathrm{R}$ is less than the median ideal point, we see from Figure 5 that the final budget $\mathrm{E}_{m}{ }^{+}(\mathrm{R})$ will exceed the reversion $R$, but will decline as $R$ increases. So when the reversion is less than the median ideal point, higher reversions should be associated with lower spending. But for reversions greater than the median voter's ideal point, a majority of voters prefers the reversion to any increase in expenditure, so for those reversions $\mathrm{E}_{m}{ }^{+}(\mathrm{R})=\mathrm{R}$ and the final budget increases with $R$.

Thus the agenda control model predicts that expenditures will always exceed the median voter's ideal level. Intuitively, the agenda setter is really using the

15 At least 36 out of 50 states use some form of this institution to allocate school expenditures. Often these involve complex formulas determined at the state constitutional level. Some also determine spending on fire, police, and other public services in this way. See Romer and Rosenthal (1979). 
FIGURE 5

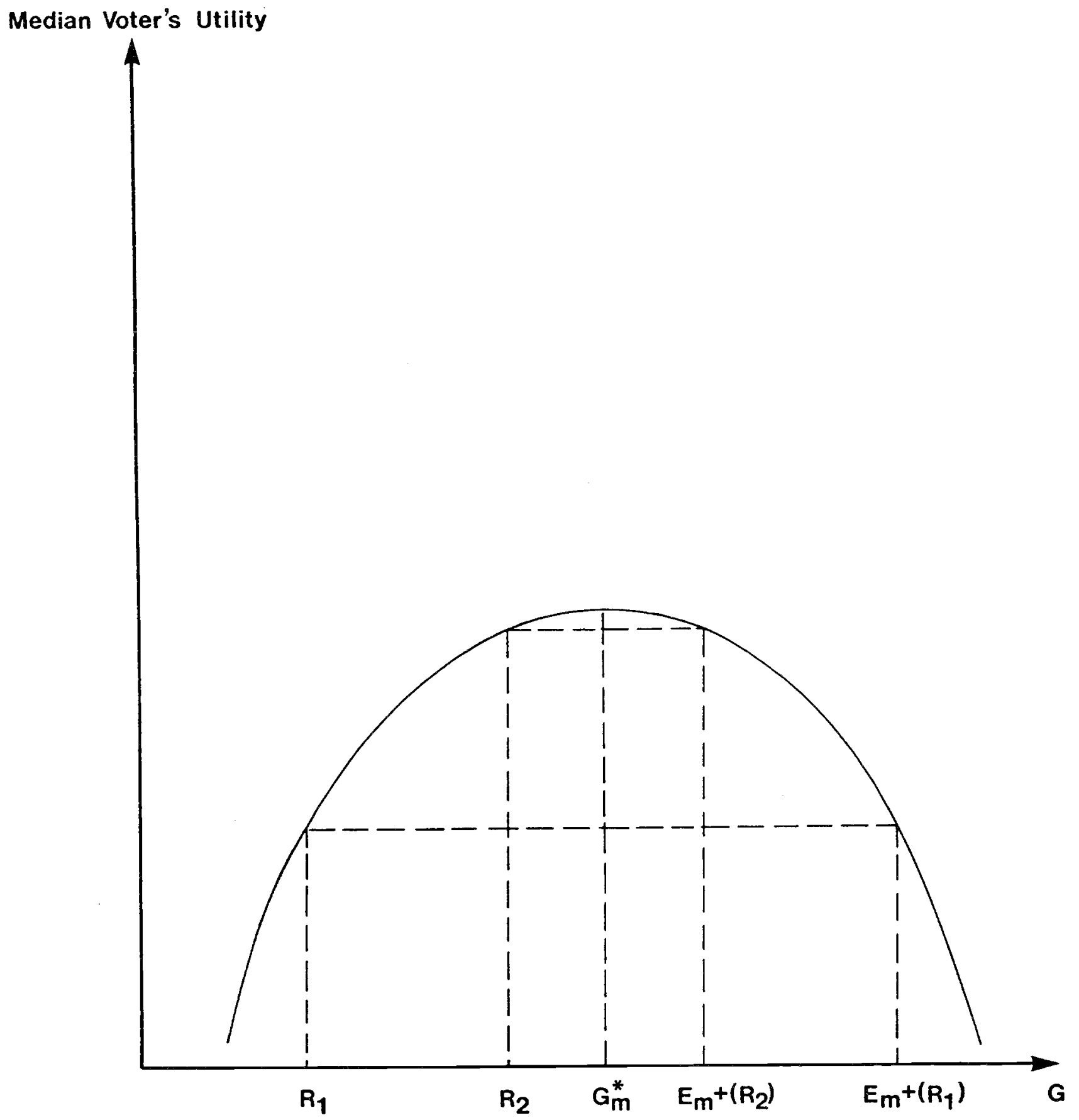


reversion as a "threat"; the equilibrium expenditure level is equal to the agenda setter's optimal proposal that drives the median voter to indifference vis-a-vis the reversion. Very low reversions - say, so low that the schools must close - pose severe threats (provide very low utility) to the median voter and therefore allow the agenda setter to extract high budgets. As the reversion increases, it provides a greater benchmark utility to the median voter, which, since preferences are single-peaked, reduces the amount of expenditure the setter can extract. Once the reversion exceeds the median voter's ideal point, the median voter prefers the reversion to any increase in expenditures, so no increase in expenditures can be approved. ${ }^{16}$

Thus, unlike the possibility that 'anything can happen' as seen in McKelvey's "chaos" theorems, the Romer and Rosenthal insight - that the exercise of agenda control is limited by institutional arrangements - provides the basis on which agenda control models can be estimated and potentially refuted empirically. Shepsle (1979), Shepsle and Weingast (1981), and Denzau and Mackay (1981) have applied this intuition as well to explain the seemingly counter-theoretical stability that characterizes legislative outcomes and processes. In contrast to the simple referenda setting, however, legislatures must decide relatively complex issues. To do so, they use a rich mix of institutions and practices that shape and color the exercise of agenda control. For instance, under many parliamentary practices, a given question is often divided into a set of sub-questions or basic issues. Each of these basic issues is then allocated to one of several standing committees, each holding responsibility for a set of predefined issues. Thus, rather than choosing allocations on every policy dimension

16 Numerous extensions and elaborations have been made to this simple model. These include investigation of the underlying sources of agenda power (Filiman, Romer and Rosenthal (1982)), the case of multiple public goods allocated by several bureaus (Denzau and Mackay (1981)), and the dynamic case where the reversion in the current period is last period's expenditure (the status quo) (Ingberman (1985)). 
simultaneously (and exposing itself to a risk of instability), a legislature may vote on "one issue at a time" via committee proposals, subject to parliamentary rules specifying what type of amendments are permitted to a committee's agenda on the question at hand and who may make such amendments. Stable, majority rule choices are shown to emerge in these more elaborate institutional settings; see the discussion in section III below. Although promising, such institutional modelling introduces a host of nontrivial research issues, not the least of which is the risk of so over-specifying the structure that the model simply reduces to description, without predictive power.

Elections, Candidate Competition, and Agenda Setter Preferences: Many of the testable restrictions of the agenda control structure follow directly from the depiction of certain political outcomes as representing the incentives of a particular decision maker, expressed subject to the constraints of institutional structure. It is probably inappropriate, however, to assume that these tastes of legislators, agenda setters, and other political actors are always exogenously defined "outside" of the political process. Budget maximization may not be the appropriate description of agenda-setter behavior. Rather, the desire to obtain and retain office can endogenously shape politicians' preferences for actions in the public arena. Agenda-setters may be better understood as agents for subsets of voters.

Clearly, then, understanding voter behavior is crucial to characterizing the behavior of agenda-setters. Yet this fact raises again the possibility of "chaos" as agenda-setters respond to the many voters' multi-dimensional preferences. Experience suggests, however, that the rich multi-dimensional complexity that underlies the "chaos" theorems may be absent in real world elections. One important paradigm associated most frequently with Downs' (1958) seminal work and with Fiorina's (1981) extensions thereof - emphasizes the notion that voters will choose to remain "rationally ignorant" of the candidates' promises and positions. Rather than seek out 
and analyze information concerning the candidates at potentially great costs, Downs supposes that voters will rely on inexpensive, readily available information, which they will then process with easily implemented heuristics. 17 One important Downsian heuristic is that parties' "positions" are proxied by ideological labels - "liberal", "conservative", "moderate", and so on. Complicated, multi-dimensional policy positions are thereby reduced to a single dimension -- the "liberal-conservative" dimension over which voters have single-peaked preferences. Competition then occurs between two parties who are solely motivated to win elections. ${ }^{18}$ Subject to certain technical conditions, ${ }^{19}$ Black's theorem applies in this Downsian world. A stable equilibrium emerges: both parties converge to the "center" and adopt the median voter's ideal point, or here, the median voter's ideal ideological label. Once again, there is no indeterminancy.

In the event that elections become multidimensional, however, Downs' model is less reassuring. As we have seen, median voter politics do not guarantee stability in the multidimensional setting without additional institutional structure. In an important contribution to this end, Kramer (1977) has provided such additional structure to the Downsian model of electoral competition. Kramer constrains the incumbent candidate in the election to run on his record, and assumes that candidates

17 Also see Enelow and Hinich (1983) who formalize a set of related ideas. They suppose that voters use candidates' position "labels" in one or a small number of "predictive dimensions" to infer, albeit imperfectly, candidate positions on issues that may arise in the future.

18 Downs also discusses multiparty competition; see Cox (1986) for recent theoretical work in this area. Other hypotheses of party/candidate motivation have been also investigated, primarily the notion that candidates have some well-behaved utility function defined over both winning and policy. See Calvert (1985) and Wittman (1983).

19 The theorem effectively requires: (1) the set of potential voters is "large", so voter participation decisions can be taken as exogenous, and (ii) voters care only about the post-election outcomes associated with the candidates, which they treat as completely and accurately described by candidate stated positions. 
tend to maximize their votes in order to obtain a "mandate". Under these conditions Kramer shows that the majority rule selection of competitive candidates produces policy trajectories that converge to a small subset of the set of Pareto optimal policies, called the minmax set. Prediction is once again possible. ${ }^{20}$

One troubling implications of Kramer's model, however, is that it predicts that the incumbent candidate will almost always lose the election: due to the generic nonexistence of a majority rule equilibrium in a multi-dimensional space, for any position the incumbent is held to, the challenger can adopt some position that defeats it. United States data suggests the opposite is true. For instance, in the U.S. House of Representatives, over $90 \%$ of incumbent Congressmen seek reelection, and over $90 \%$ of those win another term. ${ }^{21}$ The assumed constraint on the incumbent's position is the crucial and suspect assumption which forces this prediction of incumbency defeat.

Downs' arguments concerning voter information and beliefs seem especially pertinent here. Because candidates differ in many respects -- e.g., abilities, motivations, financing - voters may need to evaluate candidates according to these other, nonpolicy related attributes. Because voters have been observing the incumbent candidates performing in office, they may have much more information about the

20 By definition, the minmax set consists of all proposals for which the maximum votes against the proposal is a minimum. This set can consist of one or more policies.

In related work, McKelvey (1986) has shown that there always exists a centrally located subset of the policy space called the "uncovered set" that contains "undominated" position choices for a candidate; no candidate would rationally choose a position outside this set. Although the "chaos" theorems still hold in the sense that no single point is generically identified as a majority rule equilibrium, there are subsets of policies (i.e., the uncovered set) which can be specified, and to which majority rule politics naturally gravitates.

21 Ferejohn (1977) is a seminal paper in this area. He evaluates, and claims to refute the "gerrymandering" hypothesis (i.e., the argument that incumbent reelection chances are artificially inflated by their collusion to redraw district boundaries around ideological lines). 
incumbent than they do about the challenger. Voters might well perceive candidates as representing lotteries over post-election outcomes - induced perhaps by "rational ignorance" - rather than simply a single policy package. Models of electoral competition would do well to consider the composition and evolution of voters' information and beliefs about the candidates. Such models of electoral competition do exist; they achieve stability in the multidimensional setting through the interaction of information accumulation and political institutions. ${ }^{22}$

A Closing Caveat: Each of the models of public choice considered above rest upon the assumption that at every opportunity presented, each voter or legislator casts his ballot for their most preferred alternative, independent of how such a choice might affect future allocations. In other words, all voting is sincere. Yet we cannot rule out the possibility of strategic or sophisticated voting, of which the calculation "I like candidate X's position most, but he has little chance to win, so I'll vote for candidate $\mathrm{Y}$, who has a better chance" is but one example. It is easy to construct examples in which sophisticated voting - an individual voter or legislator temporarily misrepresenting his true preferences in order to improve his ultimate equilibrium

22 See Bernhardt and Ingberman (1985) or Ingberman (1986) for a model of incumbent-challenger competition in which voters perceive an incumbent with the same platform he had as a challenger to represent a less risky lottery than the current challenger, but an increasingly risky lottery as the incumbent deviates from his old position. Also see Enelow and Hinich (1983) for models of two-candidate competition with non-spatial characteristics, and McKelvey (1980) and Shepsle (1972) characterize the properties of two candidate competition over lotteries as a function of voters' attitudes towards risk.

Of course, many other models of electoral behavior exist. Aldrich (1983) investigated the roles of parties and nominating procedures. Cox (1986) examines primary elections and nominating procedures with more than two candidates. Much work is left to be done on the effects of campaign contributions and election financing (although see Austen-Smith (1987) or Ingberman (1986)). Finally, at least in parliamentary democracies, we are still left with the subtle and difficult question of exactly what voters think they are voting for, at least in legislative elections. Is the relevant question the ideology of the winner or the legislative outcome that will emerge, conditional on the ideology of the winner? See Austen-Smith (1983). 
payoff - changes the outcomes that result from a particular political institutional structure. $^{23}$

Stability can similarly be sensitive to the assumption of sincere or sophisticated voting. ${ }^{24}$ How important sophisticated voting is in the realities of public choice is not obvous, however. If, as Downs argues, information is costly and the benefits of informed voting small, voters can be expected to look for the most transparent and easily accessible measurement of political performance. In such a setting, unsophisticated voters may actually force politicians and agenda-setters to behave sincerely. Can a politician really defend his vote on a key issue as only a strategically useful move within a multi-stage legislative game? Probably not, particularly if the politician is being challenged by an aggressive opponent calling attention to this "anomaly" in the voting record. ${ }^{25}$ So sophisticated voting seems most likely to occur

23 For instance, consider three alternative agendas, with voters and preferences as in Table 1. Now assume (importantly!) that all voters know the preferences of all other voters, and furthermore, expect all other voters to behave strategically. As before, agenda $\alpha$ first pairs $A$ against $B$ and the winner against $C$; agenda $\beta$ first pairs $B$ against $C$ and the winner against $A$; agenda $\gamma$ first pairs $C$ against $A$ and then the winner against $B$. To find the strategic voting outcome under agenda $\gamma$, we work "backwards" up the agenda: At the last stage it can never help anyone to misrepresent their preferences (i.e., everyone votes sincerely at the last stage). Since B is to be voted on last, against the winner of $C$ versus $A$, if $B$ is paired against $A$ at the last stage, $A$ wins, while if $B$ is paired against $C$ at the last stage, $B$ wins. Thus, all voters know that a vote for $C$ at the first stage is really a vote for $B$ as the ultimate outcome, while, since it will defeat $B$ at the last stage, a vote for $A$ at the first stage is a vote for $A$ as the ultimate outcome. So the choice presented by agenda $\gamma$ is only between outcomes $A$ and B. Since a majority of voters prefer A to B, sophisticated voting produces outcome A from agenda $\gamma$, in contrast to sincere voting (which yields outcome B from agenda $\gamma$ ). In particular, voter 3 will misrepresent his preferences and vote for $A$ at the initial stage of voting, even though he prefers $C$ to $A$. The reader can verify using similar reasoning that agenda $\alpha$ results in outcome $B$, while agenda $\beta$ produces outcome C. See Ordeshook (1986, especially ch. 6) for an excellent discussion of sophistication and strategic behavior under various institutional assumptions.

24 For an example of how stability can be upset by sophisticated voting, see Denzau and Mackay (1981). For an example of how sophisticated voting can bring about stability, see Epple and Riordan (1987).

25 See Ingberman (1986), Denzau, Riker and Shepsle (1986). 
in settings not subject to public review - for example, legislative committees. The frequency of sophisticated voting and its net impact on public decisions are important empirical questions which remain to be answered. 26

\section{WHEN do we Vote?}

Each of the models reviewed above is implicitly static in context. Each player - whether candidate, voter, or legislator - is solely concerned with his current period payoffs. In some cases this may be a reasonable assumption. For example, in the single dimension version of pure majority rule, there are essentially no dynamics: each pair of candidates adopts the median voter's ideal point at every moment in time. But in other cases static and dynamic analyses have divergent predictions; in these situations an explicitly dynamic approach may be appropriate. ${ }^{27}$ Paradoxically, perhaps, the added complication of dynamic decision-making may actually enhance political stability. In static environments with sincere voting, cycling occurs precisely because players do not look forward, but rather treat each vote as a final, once-andfor-all play of the game. Once we allow voters to look forward, voting cycles need no longer emerge.

This point is made clearly in an important recent paper by Epple and Riordan (1986). They investigate the outcome of a three person divide-the-dollar (or cake)

26 See Enelow and Koehler (1980) who document several instances of sophisticated voting in the U.S. Congress. But also see Poole and Rosenthal (1982), who find that a simple one-dimensional model can correctly account for approximately $90 \%$ of individual legislators' votes in the United States Congress. Thus strategic voting, to the extent it occurs, appears to be infrequent.

27 For instance, in the Romer and Rosenthal (1979) monopoly agenda model with an exogenously determined per period reversion, equilibrium expenditures always exceed the median voter's ideal level; Ingberman (1985), however, shows that in a dynamic budgeting game, the status quo reversion rule (i.e, an endogenous reversion equal to the last period's chosen policy) can lead the setter to optimally pass budgets that fall below the median ideal point. 
game, played repeatedly. ${ }^{28}$ The three voters alternately serve as agenda setter. At each point in time, the current agenda-setter proposes a division of a dollar (or cake) among the three players. In each period the current agenda setter makes a proposal which cannot be amended; if at least one of the other two players approve the current agenda setter's proposed division, then it is implemented. Otherwise, the last period's allocation - the status quo - is implemented. It is easy to see that a static version of this game will not generate a stable outcome. But in the dynamic game, each voter, in his periodic role as agenda-setter, can punish or reward the other players for their previous behavior. Given this possibility of future retribution, the current period agenda setter may be loathe to fully exploit his or her position of power. Not surprisingly, the properties of equilibrium allocations in the Epple and Riordan model depend crucially upon the players' rates of time preference. If individuals discount the future only slightly, then voters' threats to respond to the current agenda setter's unattractive offer with similarly unattractive allocations in the future become credible. The current agenda-setter is thereby disciplined, and a stable allocation (or stable dynamic equilibrium path) can emerge.

The difficulty in the Epple and Riordan model is not the paucity of equilibria but rather their ubiquity. Depending on players' utility functions and rates of timepreference, many dynamic allocations can be equilibria. For example, two players may be able to "exile" another and split each period's cake among themselves over the infinite future. Alternatively, political cooperation or egalitarianism - i.e., equal division every period - can also emerge endogenously as equilibria to this game. In dynamic voting environments with repeat play, then, stable allocations, of ten cooperatively decided, may become the norm rather than the exception. The problem

28 See also Baron and Ferejohn (1986) who consider an analogous model of legislatures. 
now becomes to decide which of the many possible stable allocations is most likely, given the institutional structures currently in place.

\section{WHERE do we Vote?}

Up to this point we have focussed on the problem of voting cycles in majority rule politics. But as first suggested by Tiebout (1956), there may actually be no problem at all, at least in on very prominent institutional setting - the provision of local public goods through a network of competitive local governments. In effect, Tiebout postulated a political economy which operates exactly like a private market. Perfectly mobile consumers are free to locate in any one of a number of small competitive local communities (or "clubs") each of which efficiently provides a congestible public good; consumers purchase their preferred level of the public good simply by paying their chosen community's head tax or admission fee which covers the costs of producing the public good. ${ }^{29}$ Although consumers located in different communities may have different demands for the public good, mobility ensures that within any community all consumers have identical demands. So within each community there is perfect agreement, while the federalist structure of public goods provision and consumers "voting with their feet" resolves all conflicts across communities.

While the Tiebout solution to the problems of democratic fiscal choice is a clever one, it requires a very special institutional setting which may not be easily achieved. Consumers must be freely mobile between local governments; there can be no significant moving costs nor can there be any important consequences for the allocation of private goods and services with relocation. Communities must be in perfectly elastic supply so that each can replicate all attributes of their competitors at

29 See Wildasin (1986) for a careful review of the Tiebout model and its applications. 
the same per unit cost. Communities must possess some mechanism for excluding those consumers who do not pay the full costs of producing the local public good, and the payment mechanism itself must have no allocative consequences (e.g, a head tax). Finally, the public good must display congestion so that there are no significant economies of scale which might make it attractive to mix (increasingly more disparate) demand groups into a single larger and productively more efficient community. There are important situations where these institutional and economic requirements will (approximately) hold - large metropolitan areas with available land and local governments producing a congestible good like education with the right to "zone-out" unwanted consumers - but they are not likely to dominate the agenda of public activities.

Nonetheless, the Tiebout insight is a useful on two levels. First, as usually understood, decentralized federalist provision of public goods permits the diversity of choice necessary to avoid the conflict that typically results from the unitary provision of the public good. Second, even if conflict over public allocations does exist within a community (i.e, perfect sorting has not occurred), where we vote can have important implications for the overall stability of the public sector. Specifically, if consumers value stable public outcomes, they may actively search for those governmental jurisdictions that not only give them a preferred level of the public good but also hold the promise of doing so year after year. Indeed, when selecting where to live - and vote - citizens might well sacrifice a preferred expected public budget with a wide year-to-year variance for a less preferred expected budget which has less variance. Stability in fiscal choice will be encouraged thereby. 


\section{HOW do we Vote?}

Although simple majority rule is the most common form of democratic aggregation of group preferences, nothing limits us to $50 \%$ majority rule. If stability is our sole objective, there is certainly one alternative: unanimity. ${ }^{30}$ Requiring all voters to approve a move from a status quo will make any Pareto allocation a stable public choice. Democratic societies have generally not used this $100 \%$ majority rule, however, and with good reason. Under unanimity, each voter becomes a veto agent to the collective will of all others. There is likely to be too much stability in policy outcomes, which may well lead to a more fundamental social instability.

Perhaps there is a compromise between the extremes of simple majority rule and unanimity which balance the needs of stability and responsiveness? Caplin and Nalebuff (1986) find a $64 \%$ majority rule to be just such a compromise in societies satisfying two - not implausible - restrictions on voter preferences. First, voters supporting and opposing any given proposal can be divided by a hyperplane in the space of voters' most preferred points. Euclidean preferences (circular indifference curves) meet this requirement as do preferences which can be represented by a CES utility function. Second, a density function describing the distribution of voters' most preferred points must be concave. The second restriction implies a degree of social consensus on policy allocations for it rules out bimodal distributions of preferred allocations--that is, we cannot allow $40 \%$ of the voters to prefer $\$ 100$ of public spending, $20 \%$ of the voters to prefer $\$ 200$, and the remaining $40 \%$ to prefer $\$ 300$. Uniform distributions and truncated normal distributions of ideal points are allowed, however. In this setting, Caplin and Nalebuff obtain a very strong and reassuring result: a voting rule which requires a $64 \%$ majority is immune to voting cycles.

30 See Greenberg (1979). 
Further, this $64 \%$ majority rule system will be responsive to voter preferences; for example, when preferences are uniformly distributed over a policy space of $n$ dimensions, only $(.28)^{\mathbf{n}}$ of the points in the Pareto set are undominated (i.e., cannot be overturned). Perhaps herein lies the answer to the remarkable stability over the past 200 years of the U.S. Constitution with its $2 / 3$ 's majority amendment rule.

\section{Summary}

When markets and the price mechanism fail to allocate resources efficiently or fairly, it is natural for societies to turn to other institutions which might correct these failures. Government is one such institution and, for reasons of responsiveness and fairness, pure majority rule is often the preferred democratic mechanism for deciding new resource allocations. Unfortunately, the use of simple majority rule when there are three or more voters and three or more alternatives does not by itself guarantee a stable allocation. As the theory of collective choice makes clear, simple majority rule can cycle endlessly among alternative allocations. Yet democratically decided government allocations are often very stable. Why? The answer is simply that real governments do not rely upon public referenda and simple majority rule alone to make public allocations. In fact public decisions emerge from complicated institutional structures which we have sought to characterize on five dimensions: who votes, on what, when and where, and finally, how. Under pure majority rule, voting is once and for all time (when), aggregation is by the 50\% rule (how), and everyone (who) within society (where) votes on all economically feasible allocations (what). As we have seen, imposing any one, or even several, of these institutional features on simple majority rule can produce stable allocations. An accurate characterization of such institutional features - and their implications for collective decisions - is therefore imperative to any empirical study of government allocations. 


\section{DEMOCRATIC CHOICE AND FISCAL ALLOCATIONS}

The democratic determination of fiscal allocations blends past events and memories with current tastes, technologies, and political institutions to produce services, taxes, transfers, and debts. We shall survey here what we now know and offer suggestions for what we need to know before we can truly evaluate the economic performance of democratic governments. We focus particularly on the important role of political institutions in defining stable public sector allocations. Both the conclusion that discretionary democratic fiscal policy has failed as well as the conclusion that it functions well are premature.

\section{A. Expenditures}

\section{Voting on Single Outcomes}

The use of simple majority rule to determine the level of spending for a single public good generates a very natural outcome: the median position in the distribution of voters' preferred allocations. In the simple world of one public and one private good, preferences over the provision of the public good are naturally represented as a single-peaked preference ordering; see Figure 3 above. ${ }^{31}$ In this simple, but plausible case, the median voter theorem applies; the unique equilibrium fiscal allocation is the median voter's ideal point. Public allocations are thereby reduced to private decisions made by the median position voter. The analysis then relies on economic demand theory; the only real trick in using this model is to identify the median positioned voter. Bergstrom and Goodman (1973) specified five conditions sufficient to identify

31 Though Kramer and Klevorick $(1973,1974)$ obtain results for locally stable fiscal allocations when voter preferences are not everywhere single-peaked. Such results are useful for problems which naturally involve increasing returns to scale in the provision of the public good. 
the median position with the voter with the median income, and Inman (1978a)

specified, estimated, and confirmed the Bergstrom-Goodman model for one sample of majority-rule, single-dimension governments (Long Island school districts). ${ }^{32}$ Since

those papers, the median income voter model has become a cornerstone of the empirical literature on government expenditures. We shall not review all these findings here (see Inman (1979) and Rubinfeld (1987) for that) but the resulting estimates of the price and income elasticities of demand for government services are plausible and statistically significant. Further, such models succeed in explaining a sizeable fraction of the variation in government spending within their samples. One can do worse than to begin with a purely economic model of government spending which emphasizes such purely economic variables as tastes, tax prices, and incomes. ${ }^{33}$

32 The five conditions are: 1) each government represents citizens whose income distributions are simple proportional shifts of the citizens' income distributions in the other governments in the sample; 2) each citizen's tax price $(\pi)$ is a constant elasticity function of the citizen's income; 3) all citizens have a log-linear demand for public services as a function of income, the tax price, and possibly the characteristics of other citizens in the government; 4$)$ the price $(\beta)$ and income $(\alpha)$ elasticities of demand and the tax price elasticity with respect to income $(\epsilon)$ do not violate $\alpha+\beta \epsilon \neq 0$, and 5) there is no strategic voting. These restrictions are limiting but not totally unreasonable for the right sample of governments; see Inman (1978a) for one effort at justification. Goldstein and Pauly (1981) have their doubts, however.

33 However, the median voter model is not without its problems and inconsistencies. The most notable is the so-called "flypaper effect" observed for private income and public grants-in-aid. As Bradford and Oates (1971) first noted, if the median income voter model is the correct specification for government spending, then a dollar given to the government as grants-in-aid should have the same fiscal effects as a dollar given to the median voter as private income. In the median voter model the government is a perfect agent for the median voter. In fact, almost every application of the median voter model finds that a dollar of private income increases public spending by $\$ .10$ or less while a dollar of grants increases public spending by $\$ .50$ or more; see Inman (1979). Money seems to stick where it hits. There have been numerous attempts to explain this empirical anamoly within the structure of the median voter model; see Inman (1979, due to a federal tax wedge), J. Hamiliton (1986, due to the excess burden of taxation), and B. Hamilton (1983, due to misspecification of government production technologies). But each of these suggestions is insufficient as a full explanation for the observed differences in the effects of aid and income. The answer to the "flypaper" conundrum is most likely to be found in an extension of the median voter framework to allow for more than simply the calculus of household 
Yet one can often do better by adding institutions and history to the story. This important fact was brought to the analysis most clearly and forcefully by the work of Romer and Rosenthal $(1979,1982)$ in a series of important papers on onedimension, majority-rule politics with an agenda-setter. While the pure median voter model assumes that all proposals or budget levels can be presented for consideration (an "open" agenda), Romer and Rosenthal specified and tested an alternative model in which a "closed" agenda is controlled by a budget-maximizing bureaucrat; see section II.B above. Of course the agenda-setter is always free to offer the median voter's preferred budget; thus the Romer-Rosenthal model also includes the mediañ voter model as a special case.

Romer and Rosenthal test these nested models of median voter and agendasetter politics using referenda and expenditure data from a sample of Oregon school districts, each having a different reversion level. Recall from Figure 5 that the model predicts that as the reversion level decreases, public expenditures increase. In contrast, the open-agenda, median-voter model predicts government spending will be independent of the reversion level - that is, spending always equals the median voter's preferred allocation. When the two models are tested side-by-side, Romer and Rosenthal find that the reversion level has a significant negative effect on government spending - just what the agenda-setter model predicts and contrary to the prediction of the median voter model. For their sample, they find that the agendasetter's monopoly power increases a typical Oregon school district's budget by $15 \%$ over what the median income voter might have preferred. ${ }^{34}$

demand theory; see the excellent review in Fisher (1982) and the recent work of Filimon, Romer, and Rosenthal (1982).

34 Other observations found to be consistent with the setter model include: (1) lengthy school closings in Oregon have occured, after numerous defeats of the school board's proposals; (2) Oregon districts that did not hold referenda generally assessed their aggregate reversions, and essentially no proposed decreases in expenditure were 


\section{Voting on Policies with Multi-dimensional Outcomes}

Both the median voter and Romer and Rosenthal's agenda-setter models have limited empirical application, however, as they focus only on policy choices over one dimension or issue. Although there are important instances where such a restriction is plausible - e.g., special provision governments such as school districts in the United States - political decisions often encompass many issues simultaneously. As we have seen in section II, however, this fact creates special problems for stability in fiscal choice. Restrictions on voter preferences and budget constraints no longer guarantee a stable budgetary outcome. ${ }^{35}$. Once fiscal choice involves two or more policy dimensions - e.g., education and national defense - political institutions and political history are no longer simply a nice, maybe even compelling, addition to the story.

observed, exactly as predicted by the model when the reversion exceeds the median ideal point; and (3) districts with very low reversions (e.g., the schools close) generally have budgets approved with very narrow majorities as predicted by budget maximization. See Romer and Rosenthal (1979).

Although the Romer-Rosenthal model has been an important step forward in the specification and estimation of government spending behavior, we should not discard the median voter model altogether. Romer and Rosenthal reject the median voter model for their Oregon sample, but in other institutional settings it may be the correct specification. The question is fundamentally an empirical one; the answer turns on whether the Romer-Rosenthal agenda-setter has sufficient power to influence the final outcome. Ingberman (1985) shows that when the reversion level is last year's budget - called a dynamic reversion - the agenda-setter's allocation converges towards (but does not reach) the median voter's preferred allocation. Alternatively, the budgetmaximizing agenda-setter may not be capable of enforcing an all-or-nothing offer on the median voter - that is, the median voter may have the ability to remove the bureaucrat from office if he tries to exploit his position. The median voter and the agenda-setter models therefore stand side by side as equally plausible explanations for single dimension budgets. We should test them both against the data, as Romer and Rosenthal themselves have done; see Filimon, Romer and Rosenthal (1982) and also Gramlich and Rubinfeld (1982).

35 Though an interesting paper by Gevers and Proost (1978) with a comment by Parks (1979) provides one class of utility functions which are sufficient - when joined with a linear budget constraint - to given stable majority rule allocations in a two-dimension policy problem. 
Institutions and history become the essential components, for these structures are necessary for stable budgetary allocations.

In an important paper on the role of political institutions, Shepsle (1979) shows that the granting of agenda-setting power to select individuals or groups can produce stable majority rule allocations in the case of multi-dimensional policy choices. The final allocations - called structure-induced equilibria (SIE) - are conditioned by budgetary history and the constitutional rules that define this agenda-setting power. Figure 6 (similar to Figure 4 above) illustrates the basic structure of such a model. In this example there are two policy dimensions (education, $g_{1}$, and defense, $g_{2}$ ) and three voters denoted W ("rich"), M ("middle"), and P ("poor"). As with Figure 4, we assume (for convenience) that each voter has circular indifference curves about a most preferred allocation, denoted by points $\mathrm{W}^{*}, \mathrm{M}^{*}$, and $\mathrm{P}^{*}$ respectively. Recall from section II that the solid lines connecting the three "bliss" points are contract lines between pairs of voters. In this case simple majority rule will not generally provide a stable outcome. Here, however, we shall allow one group to be the agenda-setter - for example, group W. W proposes an alternative and if a majority of the three voters approves, then that alternative is chosen. Each alternative must be some combination of spending on $g_{1}$ and $g_{2}$. If no alternative is chosen within a stated period of time say by the start of the new fiscal year - then the new allocation reverts back some other pre-specified allocation, denoted by the point $\mathrm{R}$ in Figure 6. Point $\mathrm{R}$ is the reversion allocation in this model, and it plays a role identical to the reversion level in Romer and Rosenthal's one dimension policy model. As agenda-setter, $\mathrm{W}$ will select that alternative which maximizes his well-being subject to the constraints that a majority approves and that point $R$ is the reversion point.

Since $\mathrm{W}$ controls the agenda, he can limit the other voters to a take-it-or-leaveit choice between some alternative and point $R$. He prefers an allocation along the 
FIGURE 6

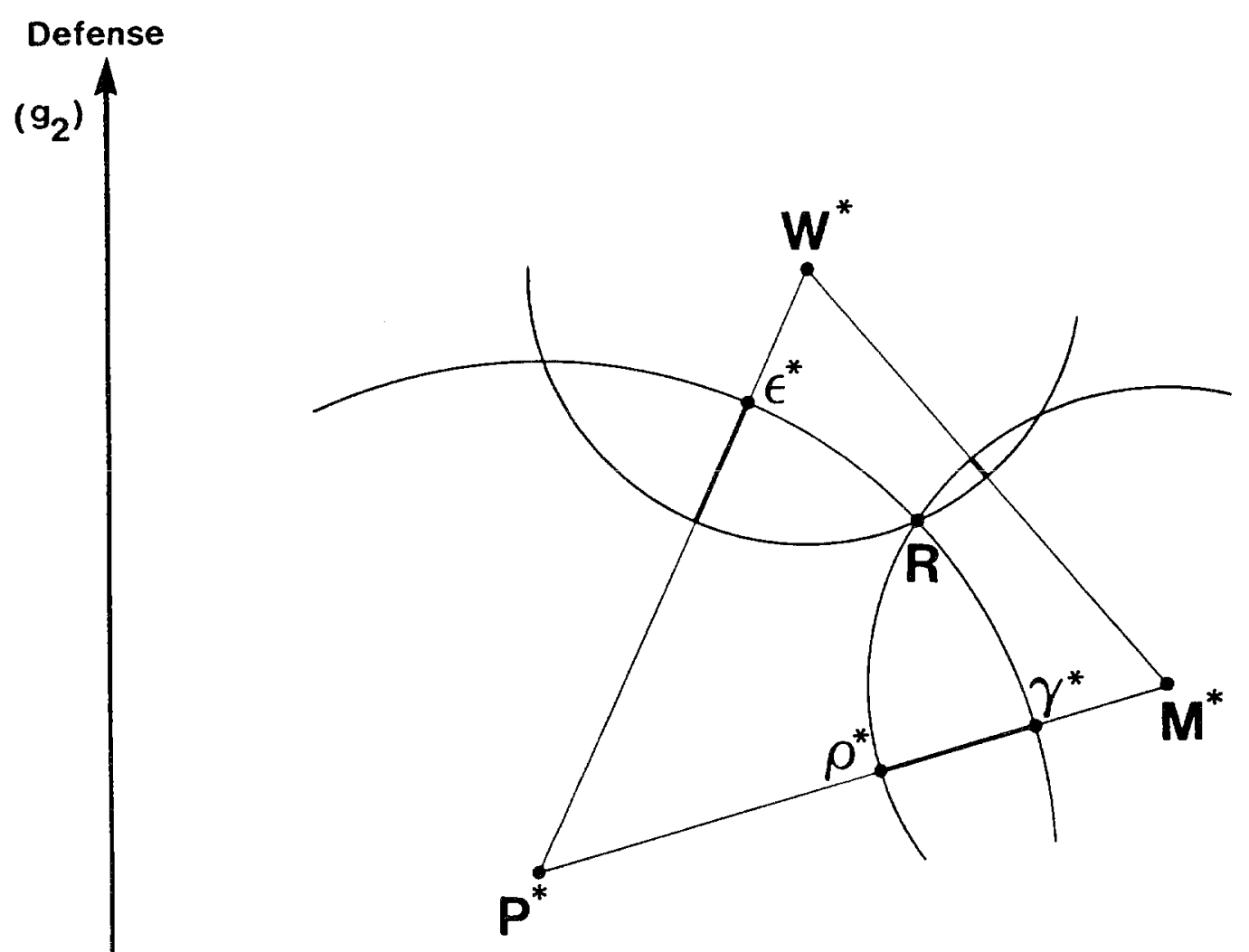


$\mathrm{W}^{*} \mathrm{M}^{*}$ or $\mathrm{W}^{*} \mathrm{P}^{*}$ contract lines; this allows him to extract as much surplus from $\mathrm{M}$ and $\mathrm{P}$ as possible. $\mathrm{M}$ and $\mathrm{P}$ will agree to vote with $\mathrm{W}$ as long as the proposed alternative improves their welfare over that offered by the reversion level R. Thus W should only consider alternatives along the heavy shaded segments of $\mathrm{W}^{*} \mathrm{M}^{*}$ and $\mathrm{W}^{*} \mathrm{P}^{*}$. Point $\epsilon^{*}$ is the best of those alternatives for the agenda-setter W. Similarly, if voter P is the agenda-setter and $\mathrm{R}$ is the reversion level, then point $\rho^{*}$ is the equilibrium allocation. Finally, point $\gamma^{*}$ will be the equilibrium allocation if we again start from $\mathrm{R}$ but $\mathrm{M}$ is the agenda-setter. All three allocations constitute a stable equilibrium, provided the political structure (institutions) and the status quo point (history) remain fixed. ${ }^{36}$

More elaborate institutional structures than simply one agenda-setter can be specified within the SIE framework; as noted in section II, real world political institutions are rich in detail. Shepsle (1979), for example, considers a model with two agenda-setters, one for each policy dimension. He calls each agenda-setter a legislative committee. Each committee offers one alternative along its policy dimension for majority-rule consideration by all voters or legislators. When deciding its preferred alternative, the committee takes the allocation along the other policy dimension as given, perhaps, for example, the policy's status quo level. Voters are then asked to vote - yes or no - on the new proposed budget consisting of a new allocation on the committee's policy dimension and (say) the status quo allocation on the other dimension. If the proposal fails, then the budget reverts back to the status quo point on both dimensions. As Shepsle recognizes, it is most likely that the two agendasetters will play a game against each other in this setting, each selecting their proposal

36 If the status quo point is not fixed then a new equilibrium will emerge. Specifically, if the budgeting process is a dynamic one in which last period's budget is the next period's status quo, then it is possible to show that the group that controls the agenda can move the final allocation arbitrarily close to its bliss point over time. Starting from $\epsilon^{*}$, for example, the next period allocation will be closer to $W^{*}$ than $\epsilon^{*}$. 
on their policy dimension so as to influence the choices of the other agenda-setter. Shepsle solves this budget game by assuming the two agenda-setters design their preferred budgets, taking the other agenda-setter's last proposal as given. The resulting equilibrium is one example of a structure-induced equilibria. 37

Although a promising format for theoretical and empirical analysis of fiscal policy-making ${ }^{38}$, there are at least two strong predictions of SIE models which do not accord well with the common patterns of budgetary politics. First, in most majority rule SIE models, fiscal allocations are decided by only a bare majority, sometimes known as the "minimum winning coalition." Second, that majority and its resulting allocations can change radically with only small shifts in the status quo point or with changes in the controlling agenda-setter. Neither implication corresponds very well to ty pically observed budgetary behavior in real democracies. More often than not, budgets are approved by large majorites, and further, they seem to deviate very little (at least in real terms) from what was done last year, even when agenda control shifts

37 The stability of the equilibrium or even its existence is by no means guaranteed, however; see Shepsle (1979).

38 Variants of Shepsle's SIE model have been proposed and employed in the analysis of fiscal policy. Mackay and Weaver (1983) have used an extension of the SIE model to examine the strategic behavior of budget maximizing agenda-setters. Ferejohn and Krehbiel (1987) use the SIE model to analyze the propensity for increased spending in the U.S. federal budgeting since the passage of the 1974 Budget and Impoundment and Control Act.

Serious econometric analysis and testing of the SIE model is only just beginning, however. Craig and Inman (1986) have specified and estimated a reduced form for an SIE budget model, examining state government allocations over education and welfare spending. While they cannot establish the precise identity and influence of the agenda-setter, their results do show the importance of the status quo point to such allocations. Structural models of a simple SIE process can also be specified and estimated. One strategy would be to 1) a priori identify the agenda-setter, 2) then model the two contract lines between the agenda-setter and each of the remaining two voter coalitions, and finally, 3) estimate the model using disequilibrium econometrics to determine each contract line and to identify the chosen allocation. 
from one voter or coalition to another. ${ }^{39}$ Multidimensional budgetary politics appears to involve more structure than simply an agenda-setter and a status quo point as emphasized by SIE models.

What is missing from these models of fiscal politics? Perhaps more any anything, it is the sense of politics as an art of compromise. Inherent in the structure of SIE models is the non-cooperative nature of fiscal choice by majority-rule processes. Communication and agreements among participants are ruled out. To bring order and stability to such non-cooperative environments, it is necessary to move beyond simple majority rule and to assign specific (e.g. agenda-setting) powers to specific voters. In these models the agenda-setter has enormous power, however. Indeed, in the simpliest case of Figure 4, the agenda-setter W may be able to achieve his bliss point at the expense of the other voters, $M$ and $P$. It is hard to believe that voters $\mathrm{M}$ and $\mathrm{P}$ would tolerate such an arrangement for very long. As Riker (1982) has pointed out in his own critique of SIE models, such a monopoly agenda-setting institution may itself be unstable in a society ruled by democracy. A more likely characterization of agenda-setting power in a true democracy would be a system of rotating agenda-setters. If this is so, then we are willing to conjecture - based upon the important recent work of Axelrod (1984), Cremer (1986) and Epple and Riordan (1987) - that a cooperative process of fiscal allocations which shares the fiscal surpluses in any period across all voters may better capture the essence of multidimensional fiscal politics. Under such a system everyone is likely to get something and that something is likely to be stable over time. No one voter dare exploit fully the advantage of being the agenda-setter, for fear of being banned from all future

39 On budget approval by large majorities, see Weingast (1979). The sizeable literature on incremental budgeting documents the stability of fiscal allocations over time within a given governmental setting; see Davis, Dempster, and Wildavasky (1974). 
allocations by the other voters. ${ }^{40}$ Stable and unanamously approved fiscal allocations are likely to result from such cooperative political agreements.

One such cooperative arrangement, called the "norm of universalism," has been described and analyzed by Weingast (1979) and its implications for fiscal policy have been developed in Weingast, Shepsle, and Johnsen (1981). ${ }^{41}$ The norm of universalism provides a cooperative institution as a solution to the uncertainty associated with democratic allocations with ex ante unknown agenda-setters in a non-cooperative majority rule game. Under the norm of universalism each voter is allowed to submit his or her preferred public budget, composed of government projects which offer positive, but diminishing, marginal benefits. The norm of universalism requires all voters to approve all projects with the understanding that all voters will share in the costs of all projects approved. Defectors are punished by having all their future projects defeated by the other voters. The final budget will be the sum of all approved projects.

These approved budgets under universalism will usually be larger than the budgets under bare majority rule where only those projects preferred by the minimum winning coalition are approved. ${ }^{42}$ Larger budgets mean larger tax costs for each

40 Epple and Riordan (1987) cite two examples in which a U.S. Senator lost all of his favorite local projects because he failed to support the fiscal agreements of his Senate colleagues.

41 Extensions of the Weingast analysis can be found in Niou and Ordeshook (1985).

42 This will be true for two reasons. First, since all voters share in the cost of each project, the tax price to each voter when deciding how much to spend on his project will be very low - for example, $1 / m$ if the $m$ voters share the costs of each project equally. Under an agenda-setting majority rule process, the agenda-setter will internalize the majority's share of all projects' costs but ignore those project costs borne by the minority. With equal tax sharing, a majority of size $\mu$ selects projects using a tax price of $\mu / m$, the percent of voters in the majority. The lower tax price under universalism $(\mu / m>1 / m)$ induces each voter to ask for a larger project. Second, rather than a majority of projects approved, all voters' projects are approved under universalism. 
voter. As compensation, however, universalism guarantees that each voter's projects will be approved. In contrast, under bare majority rule the losing minority still pays taxes but receives no projects in return. Voters will favor the adoption of the norm of universalism when the expected benefits from universalism exceed the expected benefits from continuing with bare majority rule. This is most likely when each voter's membership in a winning bare majority is uncertain: better to take your project and higher taxes with certainty than risk paying taxes and getting no project at all!

There is much case study evidence attesting to the presence of the norm of universalism within the U.S. Congress. ${ }^{43}$ In addition to these case studies, Inman (1987b) has provided the first statistical test of the effects of the norm on the size of the federal budget. He specified an expenditure model in which a bare majority budget and a budget under universalism are competing hypotheses. The alternative hypotheses were then tested for their effects on federal expenditures for state and local government grants-in-aid over the period 1948-1985. The test is structured to detect a shift in the level of Congressional spending following the Congressional reforms of 1969 to 1972 which significantly reduced the the ability of a few strong agenda-setters to control fiscal allocations; see Ornstein (1975). In effect, Congress went from a budgeting process with known agenda-setters to a process where the key points of power became more uncertain. The observed institutional response to this increased uncertainty was the emergence of budgeting under universalism; see Stockman (1986). The predicted budget outcome was increased spending, all else equal. Inman found that U.S. federal spending on one major set of domestic programs support for state and local governments - did increase significantly (by $24 \%$ in real terms) as the politics of Congressional budgeting shifted from tight control by agenda-

43 See Weingast (1979) and the references therein. 
setters to universalism. Whether these results generalize to other federal spending remains to be seen.

\section{B. Taxes and Transfers}

Redistribution of private, after-tax incomes is the essence of conflict and instability in democratic societies, but such societies do reach agreements on these matters. In its barest form, the problem of tax and transfer policy in democracies can be reduced to a one-time majority-rule redistribution game of divide-the-cake. As seen in section II, if there are 3 or more voters, then there is no stable solution to such a game. Any majority coalition can be undone; a small bribe from the minority to a member of the existing majority will be sufficient to overturn the old majority. As in the analysis of expenditure policy, the solution to this instability is to impose additional structure on the process.

That additional structure may come by first reducing what is fundamentally an $m$-dimensional policy choice - one dimension for the after-tax income each of the $m$ voters - to a policy choice on one dimension. Then if voters' preferences can be plausibly argued to be single-peaked over that single issue, Black's theorem applies, and the most preferred allocation of the median voter is the majority-rule equilibrium. This has been the approach of Romer (1975), Roberts (1977), and Meltzer and Richards (1981). ${ }^{44}$ In their models, voters are assumed to have similar preferences over the after-tax consumption $(c)$ and work effort $(e)$ but to differ in their ability $(s)$ to earn income. The first crucial restriction in the models is to limit government tax and

44 Foley (1967) was the first to propose a formal voting model of the determination of tax and transfer policy. In Foley's model the median voter is decisive, but the model does not allow for the incentive effects of taxation. Further, feasible policies are limited to linear tax schedules. The model predicts that when the median before-tax level of income is less than the average, the resulting after-tax distribution of income will be made perfectly egalitarian. 
transfer policy to linear income tax schedules of the form: $\mathrm{T}(\mathrm{I})=t \mathrm{I}-a$, where $\mathrm{I}$ is earned income and equals ability times effort $(\mathrm{I}=s e), t$ is the constant marginal tax rate, and $a$ is the level of the lump-sum subsidy $(a>0)$ or $\operatorname{tax}(a<0)$. After tax consumption to each voter equals $c$, defined as $c=(1-t) \mathrm{I}+a=(1-t)(\mathrm{se})+a$. The voter selects work effort to maximize utility. The resulting labor supply schedule is a function of the net wage from effort and the lump-sum tax or subsidy. Once $e$ has been chosen, I and then $c$ are determined as well.

Limiting the analysis to a linear tax schedule involving the two policy variables $t$ and $a$ does not appear to help us very much. We still seem to have a policy problem in more than one dimension. Invoking the government's budget constraint, however, proves to be enough (with a mild restriction on voter preferences) to collapse the two dimensions of the linear tax structure into one. Total taxes raised must equal total government spending (G). Formally, $\Sigma T(I)=G$, or with a linear tax system, $m\left(t \mathrm{I}^{\sim}-a\right)=\mathrm{G}$ or $a=t \mathrm{I}^{\sim}-(\mathrm{G} / m)$, where $\mathrm{I}^{\sim}$ is average before tax income of all $m$ voters and is itself defined as $\mathrm{I}^{\sim}=\mathrm{I}^{\sim}(a, t)$. Substituting $\mathrm{I}^{\sim}(a, t)$ into the government's budget constraint gives a single equation which implicitly relates the marginal tax rate $t$ to the lump-sum subsidy $a$. As Romer and others have shown, $a$ is monotonically increasing in $t$, provided leisure is a normal good. For most plausible economies, then, the choice of the marginal tax rate implies a (unique) choice for the level of the lump-sum subsidy; increasing the marginal tax rate means the government can pay a larger lump-sum subsidy or impose a lower lump-sum tax. Importantly, now the choice of $t$ defines $a$ and the tax-transfer policy problem becomes a decision on one dimension - the marginal tax rate, $t$.

We need one final assumption, however, before we are safely within the confines of Black's theorem. To show that voters' preferences are single-peaked, voters' preferred marginal tax rates must be ordered along the $t$ dimension and each 
voter's preferred rate must be independent of the preferred rate of other voters. Roberts (1977) shows that this condition will be met if the ordering of voters' pre-tax incomes is independent of the choice of $t$, thereby effectively ruling out strategic voting, and Romer (1977) and Meltzer and Richards (1981) show in turn that Roberts' condition holds within the structure of this model if each voter views consumption $(c)$ as a normal good. When consumption is a normal good, then pre-tax income rises with ability no matter what the value of $t$. Further, from Roberts (1977) we find that voters with higher pre-tax incomes prefer lower marginal tax rates. Preferred outcomes (i.e, voters' ideal points) can now be ordered along the one dimension, the tax rate. Black's theorem can be applied, and the equilibrium tax rate $t^{*}$ is the rate most preferred by the voter with the median level of pre-tax income or, equivalently, productive ability.

What will be the majority-rule value for $t^{*}$ ? First, $t^{*}$ is less than 1 , since: (i) the least able person prefers to make the subsidy $a$ as large as possible, but (ii) $a$ will be 0 if $t^{*} \geq 1$, since no one will work and there will be no revenues, so (iii) the least able person prefers a tax rate less than 1 , and (iv) so too must the median positioned voter, since the preferred marginal tax rate falls as ability increases. Second, $t^{*}$ is positive if and only if the average level of ability (and pre-tax income) is greater than the median level of ability (and pre-tax income). Since most measured distributions of incomes and abilities are positively skewed (i.e., where the mean is greater than the median), we can use this majority-rule model to provide an explanation for why, empirically, the marginal tax rate is bounded between zero and one. Further, from the government's budget constraint $\left(a^{*}=t^{*} \mathrm{I}^{\sim}-\mathrm{G} / m\right)$ we see that $a^{*}$ will then be positive if $\mathrm{G}=\mathrm{O}$. But if $\mathrm{G}>0, a^{*}$ may become negative - that is, when government public goods spending is large enough we may need both a positive marginal tax rate as well 
as lump-sum taxes to balance the budget. ${ }^{45}$ The model highlights a fundamental tension between the provision of public goods and support for the poor within democracies. That is an important accomplishment.

As an explanation of the actual tax and transfer systems in most Western democracies, however, the linear-tax majority-rule model is incomplete. Because it requires a fixed marginal tax rate, the model, by its nature, cannot explain one of the most prominent features of democratic tax systems, namely progressivity. ${ }^{46}$ Does democracy logically lead to progressivity? Kramer and Snyder (1983) offer one majority rule model to show that if (i) voters are restricted to considering only constant or rising marginal tax rate schedules, and (ii) the labor market divides into a tax and untaxed sector and voters' labor supply allocations between the two sectors is such that each voter's after-tax income has a unique maximum for some progressive tax schedule, then voter preferences over these tax schedules are single-peaked in income and the median voter's preferred schedule is then the majority rule outcome. If voters are only interested in maximizing their own after-tax incomes, then the resulting equilibrium tax schedule is a fixed head tax (or subsidy) for all voters with abilities (or pre-tax incomes) equal to or less than the median's, and then a high marginal tax rate on all voters with abilities greater than the median. ${ }^{47}$

45 In simulations with this model Romer shows that $a^{*}$ turns negative as public goods spending (defense, education, roads, and the like) approaches 25 percent of GNP; the U.S, at least, is near this threshold.

46 A recent $O E C D$ publication shows marginal tax rates to be rising with income in all the major Western democracies with the exception of Australia; see Kramer and Snyder (1983, Table 1).

47 Since (by assumption) marginal tax rates must be constant or rising with ability, the median voter maximizes revenue by imposing a flat tax on all lower ability voters voters up to and including himself, and maximizes revenue from more able voters by imposing a high marginal tax rate on them. Maximizing revenue from all voters below and above allows the median ability voter to minimize his own tax payments or maximize his own subsidy. 
While the resulting tax schedule from the Kramer-Snyder model does have rising marginal rates, it too falls short of a compelling explanation of most observed tax and transfer systems. First, there are only two rate classes. Second, the median ability level is the dividing point; the median voter therefore pays the same lump-sum tax or receives the same lump-sum subsidy as the poorest ability household in society. Empirically, this is rarely the case. ${ }^{48}$

The work of Romer and others on the linear-tax model and that of Kramer and Snyder on progressive rate models illustrate the limitations of a strict majorityrule approach to what is inherently a $m$-dimensional policy problem, one dimension for each of the $m$ voters. Models with more structure than strict majority rule are needed. Cukierman and Meltzer (1986b) provide such a model, employing Shepsle's framework of structure-induced equilibria. In their model, voters first decide on the average tax rate $(t)$ and the level of the transfer $(a)$ to be paid to lower income households, given the degree of tax progression (assumed to be measured by a single parameter, $\rho$, where $\rho=0$ implies proportional taxes, $\rho<0$ implies regressive taxes, and $\rho>0$ implies progressivity). As in the linear-tax models, this initially two-dimensional problem ( $a$ and $t$ ) becomes a single dimension policy problem - voting on $t$ - because of the government's budget constraint. A unique median voter equilibrium exists (under restrictions similar to those imposed in the linear tax model) which defines the majority-rule level of $t$ as $t_{\mathrm{m}}=t(\rho)$. Voters then decide on the values of $a$ and $\rho$, given a value of $t$. This decision also reduces to a one dimension policy decision - voting on $p$ - again because of the government's budget constraint; a unique median equilibrium

48 Note too, the important role that the assumed constraint that only constant or progressive rate schedules be considered plays in their analysis Without that constraint, the median income voter would favor schedules which are regressive over lower incomes and progressive over higher incomes. It is not clear that such a schedule could ever become a stable majority rule equilibrium, however. 
for $\rho$ exists defined as $\rho_{m}=\rho(t)$. With sincere voting, an overall equilibrium is defined as the intersection of these two schedules of median preferred tax parameters. ${ }^{49}$

The political structure of the Cukierman-Meltzer model is (as they admit) artificial, but it is not without motivation. The economic consequences of tax policy for the middle class will be set by the level of the lump-sum subsidy $a$ and the average rate $t$, while the consequences of policy for the poor and the rich will turn primarily on the values of $a$ and $p$, respectively. Further the middle class commands the median position. Thus the vote on the issue pair $(a, t)$ can be viewed as decision by the middle class on how to maximize its welfare knowing that larger values of $a$ increase welfare while larger values of $t$ reduce it. The vote on the pair $(a, \rho)$ is a decision to take as much as possible from the rich by increasing $\rho$ (subject to incentive effects, of course) so as to increase $a$ (holding $t$ fixed). Politically, it is a middle class vs. rich world, with the poor along for the ride. The final equilibrium is likely to have positive values of $a, t$, and $p$. There will be lump-sum subsidies and marginal tax rates which rise with income. Further, Cukierman and Meltzer argue that a larger gap between before-tax average and median incomes (assuming the average exceeds the median) will induce greater redistributions to the poor and middle classes (via $a$ ) and a larger degree of tax progressivity ( $p)$. These are testable propositions.

In the context of a general study of the growth of government, Peltzman (1980) has tested the first of these propositions, that an increase in the variance of pre-tax incomes or abilties will increase the level of transfers paid to the poor and middle classes. He tests for the presence of such a positive effect of the variance in pre-tax incomes on the level of government transfers to the poor and finds that in almost every setting examined - from $20^{\text {th }}$ century time-series data for the U.S, for Britain,

49 As with any SIE model matters of uniqueness and stability must be resolved. 
and for Canada to cross-section data for developed and less developed countries - the hypothesis is rejected. 50 In fact, the observed relationship between the variance in pre-tax incomes and redistributive spending is strongly negative: as the distribution of pre-tax incomes becomes more equal, governments spend more - not less - on redistributive activities!

The empirical rejection of the central predictions of majority-rule models of redistribution policy suggests that we may be looking in the wrong direction when we use non-cooperative, or have vs. have-not, models of government transfers and taxes. While important first steps, neither simple median voter models nor simple institutional stories of (exogenously given) agenda control by the "haves" or the "havenots" can do full justice to the complexity of motives and influences at work. Where might we turn? Focusing upon the economic motives for social insurance and the role of political institutions capable of providing, and sustaining, cooperative agreements across voters for such programs seem to us to be particularly promising avenues for future work. A cooperative model of income transfers - perhaps motivated by the uncertainites most voters face in their ability to earn, or keep, income - may be appropriate. Perhaps the "norm of universalism" can be extended to tax and transfer policies, where some voters want low-income transfers, others want old-age pensions or health insurance, and still others want investment tax credits or full-loss offsets for capital gains. $^{51}$ It is clear that we are only just beginning to understand the economic

50 The dependent variable in each of these regressions is the share of national income spent on government activities. Peltzman assumes (correctly, we believe) that most of government spending is redistributive. There is one direct test which uses low income transfers as the dependent variable, and the results there are identical to those elsewhere in the study (see, Peltzman (1980), Table 12, line 14). Peltzman uses a variety of measures of the distribuition of pre-tax incomes as an independent variable, and the results are consistent across all the measures used.

51 The fact that the level of low-income transfers, old-age pensions, and health insurance expanded in the United States just as the value of tax loopholes increased 
forces and the political institutions which determine a society's tax and transfer policies. $^{52}$

\section{Public Borrowing}

Three hypotheses have been offered in the public finance literature as rationales for the efficiency of government borrowing. Two hypotheses see debt as a response to a market failure: The first identifies incomplete intertemporal contracting opportunities as the motivation for debt, while the second relies on the inability of the market economy to fully adjust to increasing returns to scale. ${ }^{53}$ A third hypothesis not necessarily exclusive of the other two - allows government debt to work in conjunction with inefficient government taxes to finance public goods. Since tax inefficiencies typically grow more than proportionally as taxes increase, smoothing the pattern of tax collections between periods of abnormally high spending (e.g., wars)

by over $300 \%$ (from $\$ 50$ billion in 1968 to $\$ 170$ billion by 1980 ) may be more than coincidence-particularly since the major growth in both sets of policies occurred just as the agenda-setting power in the Congress was becoming more decentralized.

52 Whether employing techniques of formal modelling (for example, Wright (1986) on unemployment insurance), carefully done descriptive studies (see Ferejohn (1984) on food stamps, Marmor (1973) on Medicare-Medicaid, Moynihan (1973) on low income cash assistance, or Weaver (1982) on social security), or regression analysis (Orr (1976) on welfare benefits), detailed program by program studies is the place to begin.

For two case studies which illustrate the implicitly cooperative structure of U.S. tax policy, see Kantowicz (1985) and Jacob (1985) contrasting the alternative political styles of Presidents Carter (acting non-cooperatively) and Reagan (acting cooperatively) towards tax reform. Carter failed to achieve his objectives; Reagan succeeded. From a formal perspective, Aumann and Kurz (1977) present a cooperative game solution to the tax-transfer problem; see also Gardner (1981) Osborne (1984), and Peck (1986).

53 In the first case the private market economy fails to adequately transfer consumption goods from youth to old age; a government program of public debt creation (see Diamond (1965)) or mandatory social security (see Samuelson (1975)) may be able to correct the observed misallocation. In the second case, markets' fail to fully accomodate all the gains from increasing returns to scale. Here government deficits can play a typically Keynesian role and jog the economy from a low to a preferred high employment allocation; see Hart (1982). 
and periods of lower spending will reduce the overall costs of government finance over time. Each of these three arguments imply that government debt can provide real economic benefits to voters in society, benefits which may well motivate a compelling political economy explanation for public borrowing and debt accumulation.

Barro (1979) has provided the first empirical test of a political economic theory of government borrowing, focusing on the tax-smoothing rationale for public debt. In Barro's analysis, today's voters are efficiently linked to all future voters through intrafamily transfers called bequests. Positive bequests improve the welfare of future family members, while negative bequests (children caring for parents) are used to improve the position of current family members. Families decide the optimal allocation of family welfare over time, and Barro assumes that all bequests needed to facilitate the allocation are achieved. Government debt, therefore, has no role to play in improving intertemporal allocations; indeed, any attempt to use such debt to alter the flow of resources across generations will simply be undone by a realignment of family bequests (Barro, 1974). In Barro's economy, the job of government debt is to insure an efficient system of public finance by reallocating tax burdens from periods of abnormally high government spending to periods of lower spending. Such taxsmoothing will minimize the excess burden and collection costs of paying for public goods. Further, each voter should agree to such a use for government debt, since taxsmoothing can never hurt and it may help. There really is no need for politics in Barro's model because there is no conflict. A hired bureaucrat simply sets the future pattern of taxes and debt so as to minimize the collection and efficiency costs of paying for (an already agreed upon) level of public services. The bureaucrat will increase debt - that is, run a deficit - when government spending is higher than average or when the national tax base (e.g, income) is lower than average. In such instances, new debt lowers the tax rate needed to finance public goods and thereby 
reduces the efficiency costs of taxation. In a careful empirical analysis of U.S. government debt since 1922, Barro (1979) finds support for the main predictions of the theory: deficits are larger both in periods of abnormally high levels of government spending and in periods of abnormally low national income. Horrigan (1986) using U.S. data from 1790-1981 also finds support for the tax-smoothing hypothesis. ${ }^{54}$

Only one result from the Barro and Horrigan studies runs counter to the prediction of the tax-smoothing model. Deficits are far more responsive to declines in national income than any plausible parameters for the model might indicate. The strong effect of a fall in income on deficits is a puzzle for the tax-smoothing hypothesis, but the answer may lie in a model of debt policy which allows for a real effect of debt on incomes. When incomes fall abnormally low, perhaps voters respond by choosing to increase debt to increase incomes?

A Keynesian policy model based upon the economy's failure to efficiently accomodate increasing returns to scale does prescribe the use of government debt to increase aggregate demand and thereby stimulate aggregate employment (see Hart (1982)). There is the possibility of one unwanted side-effect of such debt stimulated increases in aggregate demand, and that is inflation. In such a model, expected real income will rise as unemployment falls, and decline as prices rise. Citizens who are fully employed will clearly be hurt by deficit financing as increases in deficits only increase national prices. They always vote no to added borrowing. Citizens who face a risk of unemployment, however, may well favor some deficit financing. As deficits rise, the fall in unemployment might dominate the concurrent increase in prices leading to a rise in a voter's expected real incomes. It is not implausible to imagine

54 Epple and Schipper (1981) advance a tax-smoothing argument for government debt created by state-local government pension underfundings. They find some support for the hypothesis in their sample of small towns in Pennsylvania. For an alternative model of such debt, see Inman (1982, 1987a). 
that in such an economy voters' preferences over alternative levels of deficits are single-peaked (Nordhaus (1975)), and further, that voters facing higher anticipated levels of unemployment will prefer higher levels of deficit financing. If so, then we can invoke Black's theorem and assign the politically preferred level of deficits to that voter with the median preference for new borrowing. Those with secure employment - upper management and workers with seniority - vote for zero deficits, while those who benefit most in a very taut economy - the unskilled and young workers - will prefer large deficits. The median position is likely to be occupied by employees without seniority working in cyclically sensitive industries. A Keynesian based political economy model of deficit financing would predict that it is to this group that the Democrats and Republicans, or Labor and Conservatives, will direct their economic policies. Such models of deficit financing have been specified and estimated to explain a "political business cycle" driven by government fiscal policy. The empirical evidence for the presence of such cycles is mixed at best. ${ }^{55}$ Our concern with this approach to understanding government debt policy is more fundamental, however. The analysis rests upon a Keynesian model of deficit financing which may be of limited applicability, both historically and for today's economy. If, as current empirical research seems to indicate, the long-run trade-off between inflation and unemployment is fully inelastic at some natural rate of unemployment, then there will be no permanent advantages to new borrowing in such a model. ${ }^{56}$ All deficits will do

55 The literature begins with Nordhaus (1975) and has been well summarized and criticized in a recent book by Fassbender and Hibbs (1981).

56 While the long-run trade-off may be vertical, the short-run trade-off - say for periods of two years or less - may well have a negative slope allowing temporary gains in lower unemployment with modest inflation. If so, political parties might try to stimulate the economy just before elections, and then pay the price with stag-flation after the election. It is not clear that rational, informed voters would tolerate such behavior, however, particularly since inflation is likely to have significant long-run consequences through interest rate uncertainity and investment disincentives. A 
is create inflation. If so, then within the model all voters should prefer zero new debt, clearly a prediction in violation of the facts.

We are left, then, with the third motivation for government debt as a possible basis for a political economy explanation of government borrowing: the need to improve intertemporal contracting. Sjoblom (1985) and Cukierman and Meltzer (1986a) develop such a model. Here government debt facilitates desired intertemporal reallocations, allocations not now available through a market economy or through a network of intra-family bequests. The fundamental source of this market failure is the inability of the current generation of working adults to guarantee negative bequests, even though such bequests are desired by all gererations as a means of sharing growing family wealth. If a current generation of working adults shares its new wealth by caring for their poorer retired parents (the negative bequest), there is no assurance that their children will care for them. Yet without such assurances (enslaving your child is illegal) the current working cohort may be discouraged from caring for its parents. If so, optimal negative bequests become infeasible and desired transfers remain undone. Coercive government debt and taxes - or equivalently, mandatory social security - is one possible solution to the problem.

In Sjoblom's (1985) model all voters wish to leave such negative bequests. The failure to commit resources from young to old leads to too little income in old-age. Both government debt - through which the current young buy bonds redeemable in

theory of debt policy based upon the short-run Phillips curve could be developed but it would require naive, myopic voters; see, for example, Fair (1978) for some evidence on the point. An interesting alternative model of political macro-policy has been recently developed by Alesina and Sachs (forthcoming) to explain government monetary policy. It assumes neither naive nor myopic voters. It does, however, require rotating agenda-setters - for example, a Democratic party which prefers to help the very poor or a Republican party which favors investment and capital formation. While originally developed as a positive theory of monetary policy, the model of Alesina and Sachs should also extend easily into a behavioral theory of deficit financing. 
their old age and whose proceeds are used to pay back the current elderly - or mandatory social security - through which the current young pay taxes to support the current elderly with the requirement that they too will be supported when they retire - can solve the problem. Debt levels or social security benefits are then to be decided by majority rule. In Sjoblom's model, the desired level of debt or social security benefits rise with age. Voter preferences are single-peaked and the median- aged voter is decisive. Since all voters (by assumption) desire negative bequests, a positive level of government debt and/or social security benefits will be provided. ${ }^{57}$

Cukierman and Meltzer (1986a) note, however, that not all voters may wish to leave negative bequests. If abilities differ across households and generations, then some current voters who expect to be richer than their children may prefer to leave positive bequests. These transfers are economically feasible, and thus for these voters mandatory social security or government debt is redundant. Every dollar which debt or social security transfers to them in their retirement years, they return to their children in increased positive bequests. It would appear that such voters are unaffected by, and thus indifferent to, the creation of public debt. Not so, for government debt or mandatory social security can have real economic consequences which affect the well-being of all voters. New debt expands the consumption set of the currently (negative) bequest constrained, which may lead to increased current period consumption in the economy as a whole. Increased aggregate current period consumption necessarily means less real resources for current period capital

57 In fact the level of public debt or social security spending chosen by the median voter may be inefficiently too large. The efficient level would balance the marginal costs of contributions over a citizen's full lifetime against the marginal benefits of transfers in old age. The median aged voter, however, takes his past contributions as given and votes for that old age benefit which balances the marginal costs of only his future contributions against the benefits of transfers in old age. Thus the median voter's marginal costs are less than the true social marginal costs and there will be a democratically approved over- provision of benefits to the elderly. See Sjoblom (1985). 
accumulation, a fall in the capital-to-labor ratio over time, a fall in real wages, and a rise in the before-tax rate of return; see Seidman (1984). New debt therefore affects all voters in this bequest constrained economy, and now the identification of the median voter (even assuming preferences are single-peaked) becomes a good deal more difficult. In the Cukierman-Meltzer framework the final pro-debt coalition will include the rich with bequests who benefit from higher interest rates and the very poor who still (despite the adverse wage effects) prefer negative bequests from their children to themselves in their old age. The median voter, however, is likely to be the middle class worker who gains little from the higher interest rate (and loses if he borrows), losses significantly from the fall in real wages, and who has only a modest bequest motive. All this points to low levels of new government debt, but with debt rising as the income distribution spreads, as the share of middle class wealth in nonhuman capital grows, and as positive bequests increase. These are testable propositions, but for now the tests remain to be done. 58

There is, however, a more fundamental omission in this debt as bequest story. If the central reason for positive government debt is to overcome the failure of markets to assure an efficient intertemporal allocation of consumption from young to old, how can we be sure a government, run by the same people who threaten to renege on their market or family commitments, can guarantee a government commitment to make transfers? Tomorrow's voters can always repeal laws passed today and thereby repudiate the public debt or cancel social security. Once again, today's working adults

58 The only empirical work we know on the determinants of government debt which uses an intergenerational transfer model as a motivation is the work of Inman (1982, 1987a) on state and local government pension underfunding. In that model current taxpayers and current public employees conspire to exploit future taxpayers by shifting current pension obligations onto future taxpayers and using the resources saved to increase current consumption. The conspiracy works to the extent such pension promises are enforceable (they are) and to the extent such underfundings are not capitalized into current taxpayers' asset holdings in land (they are probably not). 
cannot be sure they will be cared for with the same level of support they have given to today's elderly. Yet without that guarantee, they may well choose to minimize their losses and provide zero debt and social security benefits. We are back to the beginning now with no clear explanation as to why democratic governments in fact provide debt and mandatory social security. Recent analyses by Sjoblom (1985) and Hammond (1975) may provide the answer. They characterize a stable, cooperative solution for this non-cooperative allocation game between generations, a solution in which the young do take care of the old if they believe that only under these conditions will their children provide for them. We conclude that not unlike spending and taxes, the creation of government debt may best be understood as a cooperative political solution to what is originally a non-cooperative economic game.

\section{Summary}

The positive analysis of government spending, taxes, and new borrowing has produced significant and sometimes policy useful results. The median voter model enriched by the possibility of agenda-setter control has been tested and found to be a plausible framework for the analysis of democratic fiscal choice when choices are reasonably constrained to decisions along one policy dimension. The restriction is most plausible for governments purchasing a single public good and such models have been used with insight for the estimation of the incidence of local public goods (Martinez-Vazquez, 1982), for the calculation of economic inefficiency in the provision of local services (Barlow, 1970, and Sonstelie, 1982), and for the normative evaluation of federal and state grants-in-aid (Inman, 1978b). The one dimension median voter model has also been used for the analysis of tax policy and debt creation, but here with only mixed success. Median voter analysis has revealed important tensions within the process of democratic fiscal choice - tensions between the provision of public goods 
and income transfers, between rich and poor, and between young and old - but by itself the model has proven incapable of doing justice to the truly multi-dimensional nature of such fiscal allocations.

Necessarily, political economists have turned to multi-dimensional models of democratic decision-making. The move has not been easy. No longer is a careful specification of tastes and technology enough, for as Arrow has shown generally and McKelvey specifically, simple majority rule processes alone give no stable outcome in the multi-dimensional setting. Yet fiscal allocations by real democratic economies are of ten very stable. As we have seen in our review of collective choice theory, to insure stability in our predictive models of fiscal choice we need more structure. We need to understand political institutions and to know our fiscal histories, for it is institutions and history, along with tasted and technologies, which define the stable equilibrium.

That additional structure has been developed within the basic setting of a noncooperative majority rule game using, first, the institution of agenda-control and the theory of structure-induced equilibrium and, second, the institution of political compromise and issue-trading and the theory of cooperative bargaining. Both approaches have been used with some success in the analysis of spending, tax, and debt policy, but much remains to be done. At a theoretical level we need to understand the logical origins of the institutions of agenda-control and cooperation as they might evolve from the original, unstable world of tastes, technologies, and majority rule alone. ${ }^{59}$ At an empirical level we must bring together econometric methodologies and fiscal data from governments with alternative institutional

59 Shepsle and Weingast (1987) analyze the source of agenda power in legislatures from such primary conditions. Important work by Rubinstein (1982), and by Binmore, Rubinstein, and Wolinski (1985) seek to do the same for cooperative models of bargaining, although that work is limited to two players and therefore is not strictly applicable to our problem of motivating cooperation in a many-player setting with majority rule. 
structures to identify which of the competing models of fiscal choice most accurately describes how governments actually set spending, debt, and taxes. Only then can we begin to offer sound advice on how best to reform our institutions of fiscal choice.

\section{CONCLUDING REMARKS}

The sometime failure of voluntary market institutions to achieve an efficient and fair allocation of social resources raises the possibility that government institutions might somehow do it better. In varying degrees, modern industrial economies have turned to the coercive, collective choice institutions of government to ostensibly correct such market failures. Governments provide public goods, redistribute incomes, and regulate economic activities. The results are not always what we might hope. Many times the problem is simply poor information about the consequences of public policies. In such instances, contemporary public finance research has often provided the analysis needed for more informed public sector allocations; see, for example, the other essays in this volume. More often than not, however, the problem is not poor information, but rather, faulty institutions.

Governments fail to be efficient or fair not because citizens or their elected representatives do not know better, but because they do! Given (the presumption) that individuals are utility maximizing agents, we should expect such agents as they vote and as they bargain to seek their most advantageous allocation. Those advantageous allocations are often achieved at another's, or even their own long-run, expense. The over-provision of public goods by budget-maximizing agenda-setters (Romer and Rosenthal, 1979), the excessive level of transfers to the elderly in democratic societies (Sjoblom, 1985), and the inefficient financing of "pork-barrel" public projects by majority rule legislatures (Weingast, Shepsle, and Johnsen, 1981) are each examples of possible government misallocations. 
These observations raise a next question: Can we improve the allocative performance of governments, and if so, how should it be done? It is naive to assume that we as economists, lawyers, or political scientists can simply instruct governments to do it better. To alter the performance of governments we must alter the structure of how government decisions are made: agent tastes, public technologies, or the rules of collective choice. As tastes and technologies are generally immune to policy manipulations, we are left then to look for new and preferred rules of collective choice. In effect, we must seek better political institutions.

Central to this task is a careful understanding of how public institutions now influence the formation of economic policy. Analyses to date have provided a reasonably accurate picture of how single purpose, majority rule governments reach and enforce decisions, but we are only just beginning to understand the important role that political institutions play in the setting of multi-dimensional economic policies. Non-cooperative majority rule processes with monopoly or rotating agenda-setters have been modelled formally as have cooperative processes of political compromise. Good empirical studies of the formation of fiscal policy under either of these institutional structures are scarce, however. Further, empirical or theoretical political economy models of fiscal policy-making which jointly determine taxes, borrowing, and public spending have not yet been specified. Yet such analyses are central to any reasoned evaluation of institutional reform. Finally, deeper theoretical research is needed on institutional evolution within a simple majority rule setting. When political institutions are themselves endogenous, we must expect that institutions will evolve according to the incentives of government agents. There is no guarantee that an appealing institutional reform will be effective in altering allocative outcomes if voters or politicians can circumvent the reform. Theorists and empiricists interested 
in political economy have much good and important work to do before we can confidently propose a new order for conducting national fiscal policy. 


\section{References}

Aldrich, J. H. (1983), "A Downsian Spatial Model with Party Activism," American Political Science Review, Vol. 77, pp. 974-90.

Alesina, A. and J. Sachs (1987), "Political Parties and the Business Cycle in the United States: 1948-1084," Journal of Money, Credit, and Banking, forthcoming.

Atkinson, A.B, and J. Stiglitz, (1980), Lectures on Public Economics. New York: McGraw-Hill.

Aumann, R. J. and M. Kurz (1977), "Power and Taxes," Econometrica, Vol. 45, pp. 11371161.

Austen-Smith, D. (1987), "Interest Groups, Campaign Contributions, and Probabilistic Voting," Public Choice Vol. 54, pp. 120-34.

Austen-Smith, D. (1983), "The Spatial Theory of Electoral Competition: Instability, Institutions, and Information," Environment and Planning, Vol. 1, pp. 439-59.

Axelrod, R. (1984), The Evolution of Cooperation, Basic Books, New York.

Barlow, R. (1970), "Efficiency Aspects of Local School Finance," Journal of Political Economy, Vol. 78, pp. 1028-1040.

Baron, D.P. and J. Ferejohn (1987), "Bargaining and Agenda Formation in Legislatures," American Economic Review, Vol. 77, pp. 303-309.

Barro, R. (1974), "Are Government Bonds Net Wealth?" Journal of Political Economy, Vol. 82, pp. 1095-1117.

Barro, R, (1979), "On the Determination of the Public Debt," Journal of Political Economy, Vol. 87, pp. 940-971.

Bergstrom, T. and R. Goodman (1973), "Private Demands for Public Goods," American Economic Review, Vol. 63, pp. 280-296.

Bernhardt, M.D, and Ingberman D.E. (1985), "Candidate Reputations and the 'Incumbency Effect'," Journal of Public Economics Vol. 27, pp. 47-67.

Binmore, K, A. Rubinstein, and A. Wolinski (1986), "The Nash Bargaining Solution to Economic Modelling," Rand Journal of Economics, Vol. 17, pp. 176-188.

Black, D. and R.A. Newing (1951), Committee Decisions with Complementary Valuation, Glasgow: Hodge.

Black, D. (1958), Theory of Committees and Elections, Cambridge: Cambridge Univ. Press.

Bowen, H.R. (1943), "The Interpretation of Voting in the Allocation of Economic Resources," Quarterly Journal of Economics Vol. 58, pp. 27-48. 
Bradford, D. and W. Oates (1971), "An Analysis of Revenue Sharing," Quarterly Journal of Economics, Vol. 85, pp. 416-439.

Brennen, G. and J. Buchanan, The Power to Tax: Analytical Foundations of the Fiscal Constitution. New York: Cambridge University Press.

Calvert, Randall L. (1985), "Robustness of the Multidimensional Voting Model: Candidate Motivations, Uncertainity and Convergence," American Journal of Political Science Vol. 29, pp. 69-95.

Cameron, D.R. (1978), "The Expansion of the Public Economy: A Comparative Analysis," American Political Science Review Vol. 72, pp. 1243-1261.

Caplin A. and Nalebuff, B. (1987), "On 64\% Majority Rule," mimeo, forthcoming Econometrica.

Cohen, L, and Matthews, S. (1980), "Constrained Plott Equilibria, Directional Equilibria and Global Cycling Sets." Review of Economic Studies Vol. 47, pp. 975-86.

Condorcet, Marquis de (1776), "Essay on the Application of Mathematics to the Theory of Decision Making," in Condorcet, Selected Writings, K. Baker (ed.) (1976) Bobbs- Merril; Indianapolis.

Coughlin, P. and S. Nitzan (1981), "Electoral Outcomes with Probabilistic Voting and Nash Social Welfare Maxima," Journal of Public Economics, Vol. 15, pp. 113-21.

Cox, G. (1986), "Electoral Equilibrium under Alternative Voting Institutions," American Journal of Political Science, Vol. 30, pp. 83-107.

Craig, S. and R. P. Inman (1986), "Education, Welfare, and the 'New Federalism': State Budgeting in a Federalist Public Economy," in H. Rosen (ed.), Studies in State and Local Public Finance, University of Chicago Press, Chicago.

Cremer, J. (1986), "Cooperation in Ongoing Organizations," Quarterly Journal of Economics, Vol. 101, pp. 33-50.

Cukierman, A. and A. Meltzer (1986a), "A Political Theory of Government Debt and Deficits in a Neo-Ricardian Framework," mimeo, Carnegie-Mellon University.

Cukierman A. and A. Meltzer (1986b), "A Positive Theory of Progressive Income Taxation," mimeo, Carnegie-Mellon University.

Davis, O. A, M. A. H. Dempster and A. Wildavsky (1974), "Towards a Predictive Theory of Government Expenditure: U.S. Domestic Appropriations," British Journal of Political Science, Vol. 4, pp. 419-452

Davis, Otto A. and Melvin J. Hinich (1967), "A Mathematical Model of Policy Formation in a Democratic Society," in J. L. Bernd, ed, Math. Applications in Political Science, 2, Dallas: Southern Methodist Univ. Press. 
Davis, Otto A., Morris DeGroot, and Melvin J. Hinich (1972), "Social Preference Orderings and Majority Rule," Econometrica, Vol. 40, pp. 147-57.

Denzau, A. and R. Mackay (1981), "Structure-Induced Equilibrium and Perfect Foresight Expectations," American Journal of Political Science, Vol. 25, pp. 762779.

Denzau, A. and R. Parks (1979), "Deriving Public Sector Preferences," Journal of Public Economics, Vol. 11, pp. 335-352.

Denzau, Arthur and R. Mackay (1981), "Structure Induced Equilibrium and Perfect Foresight Expectations," American Journal of Political Science, Vol. 25, pp. 76279.

Denzau, A. Riker, W, and K. Shepsle (1986), "Farquharson vs. Fenno: Sophisticated Voting and Home Style," American Political Science Review Vol. 79, pp. 1117-34.

Diamond, P. (1965), "National Debt in a Neoclassical Growth Model," American Economic Review, Vol. 55, pp. 1126-50.

Downs, A. (1957), An Economic Theory of Democracy, New York: Harper \& Row, .

Enelow, J. and D. Koehler (1980), "The Amendment in Legislative Strategy:

Sophisticated Voting in the U.S. Congress," The Journal of Politics, Vol. 42, pp. 396-413.

Enelow, J.and M. Hinich (1984), Spatial Analysis of Elections, New York: Cambridge Univ. Press, .

Epple, D. and M. Riordan (1987), "Cooperation and Punishment Under Repeated Majority Voting," Carnegie Conference on Political Economy, forthcoming, Public Choice.

Epple, D. and K. Schipper (1981), "Municipal Pension Funding: A Theory and Some Evidence," Public Choice, Vol. 37, pp. 141-178.

Fair, R. (1978), "The Effects of Economic Events on the Vote for Presidents." The Review of Economics and Statistics, Vol. 60, pp. 159-73.

Farquaharson, R. (1969), Theory of Voting, New Haven, CT: Yale University Press.

Fassbender, W. and D. Hibbs (1981), Contemporary Political Economy, North-Holland Publishing Co, Amsterdam.

Fenno, R. (1966), The Power of the Purse, Little, Brown, and Company, Boston.

Ferejohn, J. (1984), "The Institutionalization of a Logroll: A Case Study of Food Stamps Legislation," mimeo, Stanford University.

Ferejohn, J. and K. Kriebel (1987), "The Budget Process and the Size of the Budget," American Journal of Political Science, Vol. 31, pp. 296-320. 
Filimon, R., T. Romer, and H. Rosenthal (1982), "Asymmetric Information and Agenda Control," Journal of Public Economics, Vol. 17, pp. 51-70.

Fisher, R. (1982), "Income and Grant Effects on Local Expenditure: The Flypaper Effect and Other Difficulties," Journal of Urban Economics, Vol. 12, pp. 324-345.

Foley, D. (1967), "Resource Allocation and the Public Sector," Yale Economic Essays Vol. 7, pp. 45-98.

Gardner, R. (1981), "Wealth and Power in a Collegial Polity," Journal of Economic Theory, Vol. 25, pp. 353-366.

Gevers, L. and S. Proost (1978), "Some Effects of Taxation and Collective Goods in Postwar America," Journal of Public Economics, Vol. 9, pp. 115-138.

Goldstein, G. and M. Pauly (1981), "Tiebout Bias on the Demand for Local Public Goods," Journal of Public Economics, Vol. 16, pp. 131-144.

Gramlich, E. and D. Rubinfeld (1982), "Micro-Estimates of Public School Demand Functions and Tests of the Tiebout and Median-Voter Hypotheses," Journal of Political Economy, Vol. 90, pp. 536-560.

Greenberg, J. (1979), "Consistent Majority Rules over COmpact Sets of Alternatives," Econometrica Vol. 47, pp. 627-36.

Hamada, K. (1973), "A Simple Majority Rule on the Distribution of Income," Journal of Economic Theory, Vol. 6, pp. 248-264.

Hamilton, B. (1983), "The Flypaper Effect and Other Anomalies," Journal of Public Economics, Vol. 22, pp. 347-362.

Hamilton, J. (1986), "The Flypaper Effect and the Deadweight Loss from Taxation," Journal of Urban Economics, Vol. 19, pp. 148-155.

Hammond, P. (1975), "Charity: Altruism or Cooperative Egoism?' in E. S. Phelps (ed.), Altruism, Morality, and Economic Theory, Russell Sage Foundation, New York.

Hart, O. (1982), "A Model of Imperfect Competition with Keynesian Features." Quarterly Journal of Economics, Vol. 97, pp. 109-38.

Horrigan, B. (1986), "The Long-Run Behavior of the Public Debt in the United States," Philadelphia Federal Reserve Working Papers, 86-15.

Hotelling, H. (1929), "Stability in Competition," Economic Journal Vol. 39, pp. 41-57.

Ingberman, D. E. (1985), "Running Against the Status Quo: Institutions for Direct Democracy Referanda and Allocations Over Time," Public Choice, Vol. 46, pp. 19-43.

Ingberman, D. E. (1986), "Spatial Competition with Imperfectly Informed Voters," PhD dissertation, Carnegie-Mellon University. 
Inman, R. P. (1978a), "Testing Political Economy's 'As If' Proposition: Is the Median Income Voter Really Decisive?" Public Choice, Vol. 33, pp. 45-65.

Inman, R.P. (1978b), "Optimal Fiscal Reform of Metropolitan Schools: Some Simulation Results," American Economic Review, Vol. 68, pp. 107-122.

Inman, R. P. (1979), "Fiscal Performance of Local Governments," in P. Mieszkowski and M. Straszheim (eds.), Current Issues in Urban Economics, Johns Hopkins University Press, Baltimore, pp. 270-321.

Inman, R.P. (1982), "Public Employee Pensions and the Local Labor Budget," Journal of Public Economics, Vol. 19, pp. 49-71.

Inman, R.P. (1987a), "Funding Teacher Pensions: Does Paul Rob Peter to Pay Mary?" University of Pennsylvania.

Inman, R.P. (1987b), "Federal Assistance and Local Services in the United States: The Evolution of a New Fiscal Order," in H. Rosen (ed.), Fiscal Federalism, University of Chicago Press, Chicago.

Inman, R.P. (1987c), "Markets, Governments, and the New Political Economy," in in A. Auerbach and M. Feldstein (eds.), Handbook of Public Economics, Vol. II, North-Holland Publishing Co, New York.

Jacob, C. E. (1985), "Reaganomics: The Revolution in American Political Economy," Law and Contemporary Problems, Vol. 48, pp. 7-30.

Jessop, B. (1977), "Recent Theories of the Capitalist State," Cambridge Journal of Economics Vol. 1, pp. 353-73.

Kantowicz, E. (1985), "The Limits of Incrementalism: Center's Efforts at Tax Reform," Journal of Political Analysis and Management, Vol. 4, pp. 217-233.

Kramer, G. and A. Klevorick (1973), "Social Choice on Pollution Management: The Genossenschaften," Journal of Public Economics, Vol. 2, pp. 101-146.

Kramer, G. and A. Klevorick (1974), "Existence of Local Cooperative Equilibrium in a Class of Voting Games," Review of Economic Studies, Vol. 41, pp. 539-547.

Kramer, G. and J. Snyder M. (1983), "Fairness, Self-Interest, and the Politics of the Progressive Income Tax," Cal Tech Working Papers 498.

Kramer, G. (1977), "A Dynamical Model of Political Equilibrium," Journal of Economic Theory, Vol. 16, pp. 310-34.

Ledyard, J. (1984), "The Pure Theory of Two-Candidate Elections," Public Choice, Vol. 44 , pp. $1-60$.

Mackay R. and C. Weaver (1983), "Commodity Bundling and Agenda Control in the Public Sector," Quarterly Journal of Economics, Vol. 98, pp. 611-636. 
Manley, J. F. (1970), The Politics of Finance, Little Brown and Company, Boston.

Marmor, T. (1973), The Politics of Medicine, Aldine Publishing Co, Chicago.

Martinez-Vazquez, J. (1982), "Fiscal Incidence at the Local Level," Econometrica, Vol. 50, pp. 1207-1217.

May, K. (1952), "A Set of Independent, Necessary and Sufficient Conditions for Simple Majority Rule." Econometrica Vol. 20, pp. 680-684.

McKelvey, R. D. (1986), "Covering Dominance and Institution Free Properties of Social Choice," American Journal of Political Science, Vol. 30, pp. 283-314.

McKelvey, R. D. (1976), "Intransitivities in Multidimensional Voting Models and Some Implications for Agenda Control, "Journal of Economic Theory, Vol. 16, pp. $472-82$.

McKelvey, R. D. (1979), "General Conditions for Global Intransitivities in Formal Voting Models" Econometrica, Vol. 47, pp. 1085-1112.

Meltzer, A. and S. Richard (1981), "A Rational Theory of the Size of Government," Journal of Political Economy, Vol. 89, pp. 914-927.

Miller, N. (1980), "A New Solution Set for Tournaments and Majority Voting," American Journal of Political Science, Vol. 24, pp. 68-96.

Moynihan, D. (1973), The Politics of Guaranteed Income, Random House, New York.

Mueller, D. (1979), Public Choice, Cambridge: Cambridge Univ. Press.

Niou, E, and P. Ordeshook (1985), "Universalism in Congress," American Journalism of Political Science, Vol. 29, pp. 246-258.

Niskanen, William (1971), Bureaucracy and Representative Government, Chicago: Aldine.

Nordhaus, W. (1975), "The Political Business Cycle," Review of Economic Studies, Vol. 42, pp. $164-190$.

O'Connor (1973), The Fiscal Crisis of the State, New York: St. Martins Press.

Olson, Mancur (1968), The Logic of Collective Action, Cambridge, MA: Harvard Univ. Press.

Ordeshook, P.C. (1986), Game Theory and Political Theory, New York: Cambridge Press.

Ornstein, N. (1975), Congress in Change, Praeger, New York.

Orr, L. (1976), "Income Transfers as a Public Good: An Application to AFDC," American Economic Review, Vol. 66, pp. 359-371. 
Osborne, M. (1984), "Why Do Some Goods Bear Higher Taxes Than Others?" Journal of Economic Theory, Vol. 32, pp. 301-316.

Palfrey, T. and H. Rosenthal (1985), "Voter Participation and Strategic Uncertainity," American Political Science Review, Vol. 79 pp. 62-78.

Parks, R. (1979), "Comment on 'Some Effects of Taxation and Collective Goods in the Postwar U.S.A.," Journal of Public Economics, Vol. 12, pp. 263-266.

Peck, R. M. (1986), "Power and Linear Income Taxes: An Example," Econometrica, Vol. 54, pp. 87-94.

Peltzman, S. (1980), "The Growth of Government," Journal of Law and Economics, Vol. 23, pp. 209-287.

Plott, Charles R. (1967), "A Notion of Equilibrium under Majority Rule," American Economic Review, Vol. 57 pp. 787-806.

Poole, K., and H. Rosenthal (1982), "A Spatial Model for Legislative Roll Call Analysis," American Journal of Political Science Vol. 29 pp. 357-84.

Riker, W. (1982), "Implications from the Disequilibrium of Majority Rule for the Study of Institutions," American Political Science Review, Vol. 74, pp. 432-446.

Roberts, K. (1977), "Voting over Income Tax Schedules," Journal of Public Economics, Vol. 8, pp. $329-340$.

Romer, T. (1975), "Individual Welfare, Majority Voting and the Properties of a Linear Income Tax," Journal of Public Economics, Vol. 4, pp. 163-185.

Romer, T. and H. Rosenthal (1979), "Bureaucrats vs. Voters: On the Political Economy of Resource Allocation by Direct Democracy," Quarterly Journal of Economics, 93: 562-587.

Romer , T. and.H. Rosenthal (1982), "Median Voters or Budget Maximizers: Evidence from School Expenditure Referenda," Economic Inquiry, Vol. 20, pp. 556-578.

Romer T, and H. Rosenthal (1987), "Modern Political Economy and the Study of Regulation,". in E.E. Bailey, (ed.), Public Regulation: New Perspectives on Institutions and Policies, Cambridge: MIT Press.

Rubinfeld, D. (1987), "The Economics of the Local Public Sector," in A. Auerbach and M. Feldstein (eds.), Handbook of Public Economics, Vol. II, North-Holland Publishing Co, New York.

Rubinstein A. (1982), "Perfect Equilibrium in a Bargaining Model," Econometrica, Vol. 50, pp. $97-109$.

Samuelson, P. (1975), "Optimum Social Security in a Life-Cycle Model," International Economics Review, Vol. 16, pp. 539-544. 
Schofield, Norman (1976), "Instability of Simple Dynamic Games," Review of Economic Studies Vol. 45 pp. 575-94.

Seidman, L. (1984), "Conversion to a Consumption Tax: The Transition in a Life-Cycle Growth Model," Journal of Political Economy, Vol. 92, pp. 247-267.

Sen, Amartya K., Collective Choice and Social Welfare, San Francisco: Holden Day, 1970.

Shepsle, K. (1972), "The Strategy of Ambiguity: Uncertainty and Electoral Competition." American Political Science Review Vol. 66 pp. 555-68.

Shepsle, K. (1979), "Institutional Arrangements and Equilibrium in Multidimensional Voting Models," American Journal of Political Science, Vol. 23, pp. 27-59.

Shepsle, K. and B. Weingast (1981), "Structure-Induced Equilibrium and Legislative Choice." Public Choice, Vol. 37, pp. 503-19.

Shepsle, K. and B. Weingast (1984), "Uncovered Sets and Sophisticated Voting Outcomes with Implications for Agenda Institutions," American Journal of Political Science, Vol. 28, pp. 49-74.

Shepsle, Kenneth and Barry Weingast, (1986) "Institutional Foundations of Committee Power," mimeo, Washington University, St. Louis.

Sjoblom, K. (1985), "Voting for Social Security," Public Choice, Vol. 47, pp. 225-240.

Slutsky, S. (1979), "Equilibrium under a Majority Voting," Econometrica, 47: 1113-25.

Sonstelie, J. (1982), "The Welfare Cost of Free Public Schools," Journal of Political Economy, Vol. 90 , pp. $794-808$.

Stockman, D. (1986), The Triumph of Politics: The Inside Story of the Reagan Revolution, New York: Harper and Row, Inc.

Tiebout, C. (1956), "A Pure Theory of Local Government Expenditures," Journal of Political Economy, Vol. 60, pp.415-424.

Weaver, C. (1982), Crisis in Social Security: Economics and Political Origins, Duke University Press, Durham, N.C.

Weingast, B. (1979), "A Rational Choice Perspective on Congressional Norms," American Journal of Political Science, Vol. 23, pp. 245-262.

Weingast, B. and M. Moran (1983), "Bureaucratic Discretion or Legislative Control? Regulatory Policy-Making by the FTC," Journal of Political Economy, Vol. 89, pp. 642-664.

Weingast, B., K. Shepsle, and C. Johnsen (1981), "The Political Economy of Benefits and Costs: A Neoclassical Approach to Distributive Politics," Journal of Political Economy, Vol. 89, pp. 642-664. 
Wildasin, D. (1986), Urban Public Finance. New York: Harwood Academic Publishers.

Wittman, D. (1983), "Candidate Motivation: A Synthesis of Alternatives," American Political Science Review, Vol. 77, pp. 142-57.

Wright, R. (1986), "The Redistributive Roles of Unemployment Insurance and the Dynamics of Voting," Journal of Public Economics, Vol. 31, pp. 377-399. 